\title{
Paleocene-Eocene migmatite crystallization, extension, and exhumation in the hinterland of the northern Cordillera: Okanogan dome, Washington, USA
}

\author{
Seth C. Kruckenberg ${ }^{\dagger}$ \\ Donna L. Whitney \\ Department of Geology and Geophysics, University of Minnesota-Twin Cities, Minneapolis, Minnesota 55455, USA
}

Christian Teyssier

Department of Geology and Geophysics, University of Minnesota-Twin Cities, Minneapolis, Minnesota 55455, USA

Institut de Géologie et de Paléontologie, Anthropole, Université de Lausanne, CH-1015, Lausanne, Switzerland

C. Mark Fanning

W. James Dunlap*

Research School of Earth Sciences, Australian National University, Canberra, ACT 0200, Australia

\section{ABSTRACT}

The Okanogan gneiss dome, Washington, is located in the hinterland of the North American Cordillera and is part of a chain of metamorphic core complexes containing gneiss and migmatite domes exhumed during Eocene extension of thickened crust. $\mathrm{U}-\mathrm{Pb}$ sensitive high-resolution ion microprobe (SHRIMP) analyses of zircon, monazite, and titanite, and ${ }^{40} \mathrm{Ar}-{ }^{39} \mathrm{Ar}$ analyses of biotite from migmatites exposed in the footwall of the Okanogan detachment, coupled with a detailed structural analysis, document the timing and duration of migmatite crystallization and indicate coeval crystallization, extensional deformation, and exhumation of the dome. Okanogan migmatites are folded and deformed, and preserve successive generations of leucosomes generated by synkinematic anatexis.

Analyses of migmatite samples from a highmelt fraction subdome near Stowe Mountain suggest that the Okanogan dome records a history of migmatite crystallization spanning at least $12 \mathrm{~m} . \mathrm{y}$., as indicated by ${ }^{206} \mathrm{~Pb} /{ }^{238} \mathrm{U}$ ages ranging from ca. 61 to 49 Ma for new zircon growth and rim overgrowths attributed to migmatite crystallization. Zircons from a granodiorite in a domain of diatexite near Stowe Mountain preserve rims that have a mean ${ }^{206} \mathrm{~Pb} /{ }^{238} \mathrm{U}$ age of $51.1 \pm 1.0$ Ma for the youngest population attributed to migmatite

†E-mail: kruc0030@umn.edu

*Present address: Department of Geology and Geophysics, University of Minnesota-Twin Cities, Minneapolis, Minnesota 55455, USA crystallization. Zircon from folded and discordant granitic leucosome in the diatexite domain yields a calculated ${ }^{206} \mathrm{~Pb} /{ }^{38} \mathrm{U}$ age of $53.5 \pm 0.5$ Ma for migmatite crystallization. Zircon from discordant leucosome of the metatexite domain has a mean ${ }^{206} \mathrm{~Pb} /{ }^{238} \mathrm{U}$ age of $59.8 \pm 0.5 \mathrm{Ma}$, with ages as young as ca. $53 \mathrm{Ma}$ attributed to final crystallization of the leucosome. Core domains of zircon samples have ${ }^{206} \mathrm{~Pb} /{ }^{238} \mathrm{U}$ ages that range from ca. 85 to $70 \mathrm{Ma}$ and are interpreted to be related to an earlier phase of the orogeny. Monazite from two samples gives ${ }^{206} \mathrm{~Pb} /{ }^{238} \mathrm{U}$ crystallization ages of $52.9 \pm 0.6 \mathrm{Ma}$ for the granodiorite diatexite and 52.0 $\pm 0.6 \mathrm{Ma}$ for nearby boudinaged and foliated layers of biotite granodiorite. One sample of folded granitic leucosome in metatexite contains titanite with a mean ${ }^{206} \mathrm{~Pb} /{ }^{238} \mathrm{U}$ age of $47.1 \pm 0.5 \mathrm{Ma}$. The ca. $47 \mathrm{Ma}$ age for titanite is similar to biotite ${ }^{40} \mathrm{Ar}-{ }^{39} \mathrm{Ar}$ ages of $48.0 \pm 0.1 \mathrm{Ma}, 47.9 \pm 0.2 \mathrm{Ma}$, and 47.1 $\pm 0.2 \mathrm{Ma}$ for samples collected from the upper detachment surface downward over $1.5 \mathrm{~km}$ of structural thickness into the migmatite domain.

Crystallization of the Okanogan migmatites was therefore coeval in part with upper crustal extension and ductile flow of the mid-crust. Leucosome crystallization largely ceased by ca. 49 Ma, followed by rapid cooling of footwall rocks through $\sim 325{ }^{\circ} \mathrm{C}$ by ca. $47 \mathrm{Ma}$. These data are similar to crystallization ages in migmatites from other domes in the northern Cordillera hinterland, suggesting that crustal anatexis was widespread over much of the mid-crust during Paleocene to Eocene time, coeval with extension and exhumation of orogenic middle crust.
Keywords: Omineca belt, geochronology, partial melting, gneiss dome, metamorphic core complex, migmatite, Okanogan dome, continental tectonics.

\section{INTRODUCTION}

In recent years there has been increased recognition that partial melting is a major orogenic process that affects the construction and collapse of mountain systems. Geophysical surveys in young and active orogens (Tibetan PlateauHimalaya: Nelson et al., 1996; Andean Altiplano: Schilling and Partzsch, 2001; Pyrenees: Pous et al., 1995) have revealed that much of the orogenic crust contains a significant fraction of partial melt ( 20 vol\%) at mid to lower crustal depths (>10-20 km).

The presence of a thick partial melt layer in actively deforming orogens has important implications for crustal rheology and the thermalmechanical evolution of orogens. The presence of large volumes of partially molten crust may contribute significantly to crustal flow in orogens (Royden, 1996; McKenzie et al., 2000; Beaumont et al., 2001; Soula et al., 2001; Babeyko et al., 2002; Teyssier and Whitney, 2002), especially when crustal flow at depth is coupled with upper crustal extension (Rey et al., 2001) or enhanced erosion (Beaumont et al., 2001; Jamieson et al., 2002). Flow of orogenic crust may: (1) contribute to building orogenic plateaus through lateral flow of the partial melt layer (Royden, 1996; Royden et al., 1997; Clark and Royden, 2000; Beaumont et al., 2001); (2) facilitate or drive lateorogenic extensional collapse and detachment formation (Bertotti et al., 2000; McKenzie et al.,

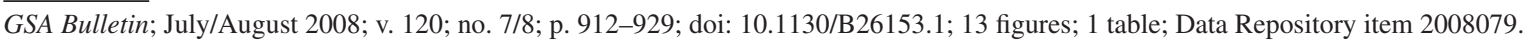


2000; Vanderhaeghe and Teyssier, 2001); and (3) affect the thermal budget of orogens through diapiric ascent of the partially molten layer to form gneiss and migmatite domes (Soula et al., 2001; Teyssier and Whitney, 2002).

Field analysis of high-grade metamorphic rocks in collapsed orogens is central to evaluation of these ideas about the role of partially molten crust in orogeny and the thermal and mechanical consequences of crustal flow. Many exhumed orogens are characterized by a highgrade core of middle to lower crustal rocks exposed in the footwall of large detachment faults, resulting in the characteristic metamorphic core complex geometry (Coney et al., 1980; Crittenden et al., 1980; Armstrong, 1982). Therefore, metamorphic core complexes, particularly those that contain substantial regions of migmatite, are excellent sites to study the field record of flow involving partially molten crust.

It has long been known, based on pioneering work in metamorphic core complexes (Coney et al., 1980; Crittenden et al., 1980; Lister and Davis, 1989), that extension in the upper crust is accommodated by ductile flow of the mid to lower crust. This ductile flow may involve a low-viscosity layer of partially molten rock. In many metamorphic core complexes, a carapace of high-grade metamorphic rocks exposed in the footwall of detachment systems mantles one or more domal structures composed of high-melt fraction migmatites, interpreted to be anatectic in origin (Whitney et al., 2004). In addition, the application of high-spatial resolution geochronology techniques has shown that dome migmatites formerly considered "old basement" are in fact the exhumed expression of the low-viscosity layer of partially molten crust (e.g., Gans, 1987; MacCready et al., 1997; Vanderhaeghe et al., 1999; Ledru et al., 2001). Furthermore, geochronology and thermochronology from numerous orogens increasingly document short time intervals for the crystallization, exhumation, and cooling of dome migmatites, detachment faulting, and extensional basin development (e.g., Keay et al., 2001; Whitney et al., 2003). This strongly suggests that the dynamics of the partially molten layer and upper crustal deformation are temporally and kinematically linked.

In order to more fully explore the role of crustal flow in the exhumation of the partially molten crust and its interactions with upper crustal deformation, studies of these systems need to address: (1) the timing of melt crystallization in migmatites relative to the structural development of domes and metamorphic core complexes; (2) the duration of crustal melting and whether anatexis was a continuous or discontinuous process; and (3) the timing and rate of cooling of dome lithologies relative to the age of melt crystallization.

In this paper, we describe the temporal relationships among partial melting, the cooling of dome migmatites, and the structural development of the Okanogan dome in Washington state (USA). The Okanogan gneiss dome is part of a belt of metamorphic core complexes and gneiss domes that extends from British Columbia (Canada) into Washington and Idaho (USA).

\section{GEOLOGICAL FRAMEWORK}

The Okanogan gneiss dome lies within the interior of the Omineca crystalline belt near its southernmost limit, and is structurally correlative with rocks of the Shuswap metamorphic core complex of British Columbia (Figs. 1 and 2 ). The tectonic history of the Okanogan gneiss dome involved Jurassic and Cretaceous crustal thickening, shortening, and metamorphism associated with terrane accretion to the western margin of North America (Armstrong, 1982; Monger et al., 1982; Archibald et al., 1983; Brown and Read, 1983; Okulitch, 1984), and Early Tertiary tectonic denudation, regional extension, voluminous plutonism and volcanism, and exhumation of high-grade metamorphic rocks (including migmatites) by detachment tectonics (Hansen and Goodge, 1988; Parrish et al., 1988).

The nearly 100-km-wide Okanogan gneiss dome is part of a larger composite structural and metamorphic culmination that includes the Kettle gneiss dome to the east and is bounded to the east and west by the Kettle and Okanogan detachments, respectively. These 1- to 2-kmthick mylonite zones define the major structural fabric at the periphery of the domes and grade upward into a diffuse zone of chloritic breccia near the contact with the upper plate (Goodge and Hansen, 1983; Hansen and Goodge, 1988). These detachment zones display consistent kinematic criteria with top to the east shear sense on the Kettle detachment and top to the west-northwest shear sense on the Okanogan detachment (Fig. 2), consistent with east-west regional extension. The composite Okanogan-Kettle complex is cut at its core by three en echelon graben oriented northeast-southwest, the Toroda Creek, Republic, and Keller graben (Fig. 2), which are bounded by high-angle normal faults.

\section{Overview of Petrology and Structure of the Okanogan Gneiss Dome}

Lithologies exposed in the core of the Okanogan gneiss dome can be broadly divided into four groups: (1) upper amphibolite-granulite facies layered paragneiss (including migmatites), quartzofeldspathic banded gneiss, amphibolite, and minor calc-silicate rocks that make up the Tonasket gneiss (Snook, 1965; Fox et al., 1976); (2) orthogneiss, commonly with megacrystic augen, that intruded and structurally overlies the Tonasket gneiss; (3) the amphibolite facies Tenas Mary Creek Sequence, exposed primarily in the NE Okanogan dome and correlative with rocks of similar type in the Kettle dome, including pelitic schist, quartzite, marble, interlayered orthogneiss, and minor amphibolite rocks (Cheney, 1980); and (4) early Tertiary granitic gneiss and granodioritic plutons of the Colville Batholith that are variably mylonitized and that concordantly intruded the Tonasket gneiss and mantling orthogneiss (Fox et al., 1976, 1977; Holder and Holder, 1988; Carlson and Moye, 1990).

The metamorphic pressure-temperature-time (P-T- $\mathrm{t}$ ) paths of rocks from the Okanogan-Kettle gneiss domes are not well known. The metamorphic rocks of the Okanogan dome are generally characterized as upper amphibolite facies (Snook, 1965; Goodge and Hansen, 1983; Menzer, 1983; Hansen and Goodge, 1988). Goodge and Hansen (1983) and Hansen and Goodge (1988) confirmed that rocks of the Tonasket gneiss in the SW Okanogan dome experienced upper amphibolite facies metamorphism and reached the sillimanite + K-feldspar zone. Snook (1965) proposed that some rocks of the Okanogan dome experienced granulite facies conditions based on relics of spinel, corundum, and olivine in amphibolite. In addition, Harvey (1994) documented a suite of unusual minerals in a sapphirine-bearing amphibolite in the western part of the dome south of Stowe Mountain (Fig. 2), providing the first quantitative estimates of metamorphic conditions of $\sim 10$ kbar and $\sim 825^{\circ} \mathrm{C}$. The upper amphibolite facies assemblages are locally overprinted by greenschist-facies minerals; e.g., epidote and chlorite near late faults and shear zones.

Structural features in footwall units of the Okanogan dome include well-developed, shallowly dipping gneissic foliation, pervasive lineation, micro- to meso-scale folds, mylonites, breccia, and a series of northwest-trending, doubly plunging anticlines or subdomes that warp the regional fabric. Two of these smaller domal features are defined as regions of radially dipping foliations in the Tonasket gneiss and are informally named the Burge and Stowe Mountain subdomes (Fig. 2). These subdomes expose the lowest structural levels in the complex and contain migmatite in their cores.

In the Stowe Mountain region along the western margin of the Okanogan complex (Fig. 2), a continuous structural section exposes the transition from a domain of migmatite within the Tonasket gneiss upward to the base of the Okanogan detachment mylonite (Fig. 3). Fold 


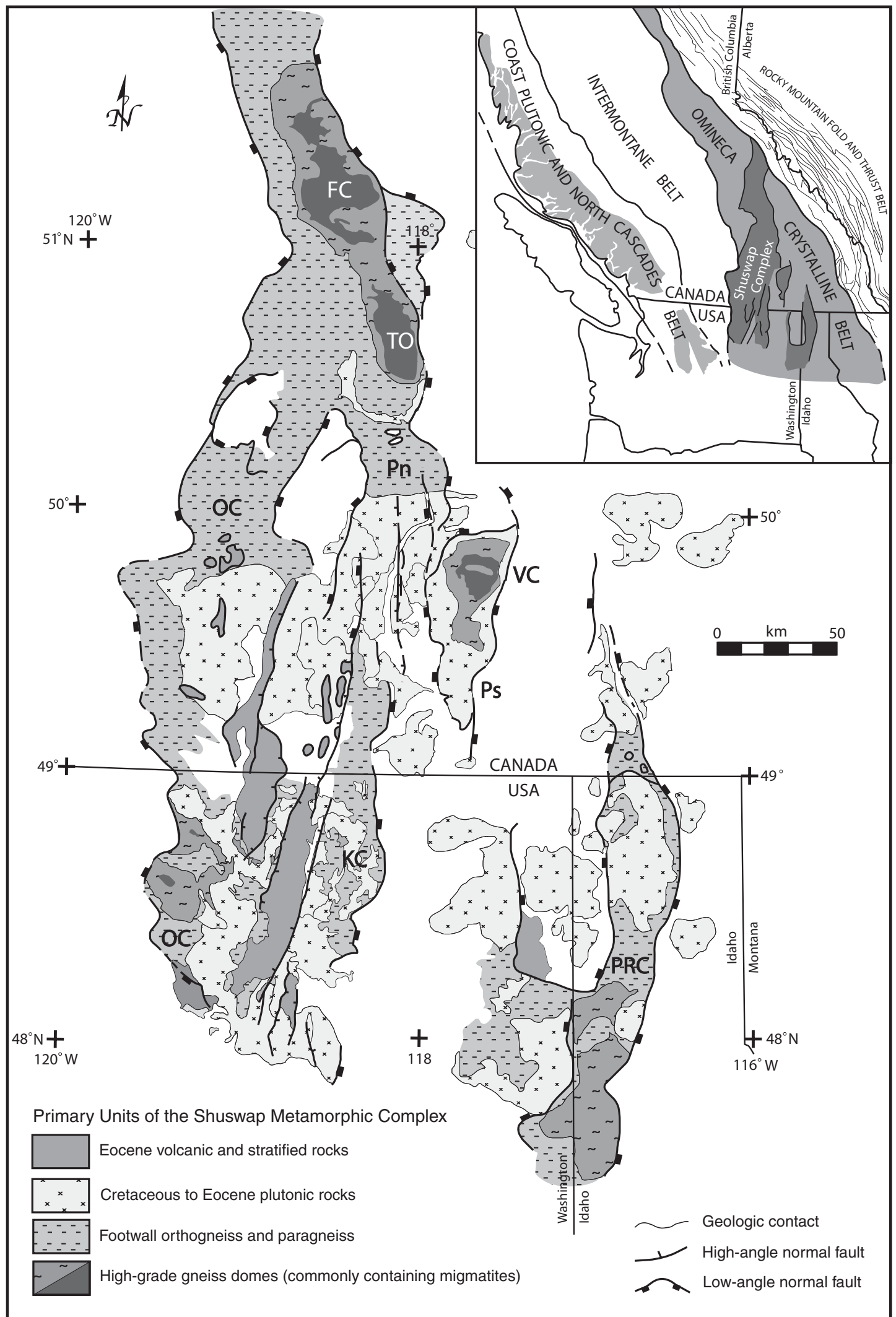

Figure 1. Simplified geologic map of the southern Omineca belt (after Parrish et al., 1988; Stoffel et al., 1991; Doughty and Price, 1999). Inset shows tectonic belts of the northern Cordillera. High-grade gneiss domes within the Shuswap complex from north to south are: FC-Frenchman Cap; TO_Thor-Odin; Pn—Pinnacles; VC_-Valhalla Complex; Ps-Passmore Complex; PRC_Priest River Complex; KC_Kettle Complex; OC-Okanogan Complex (note: north of the 49th parallel, Okanogan is spelled Okanagan). 

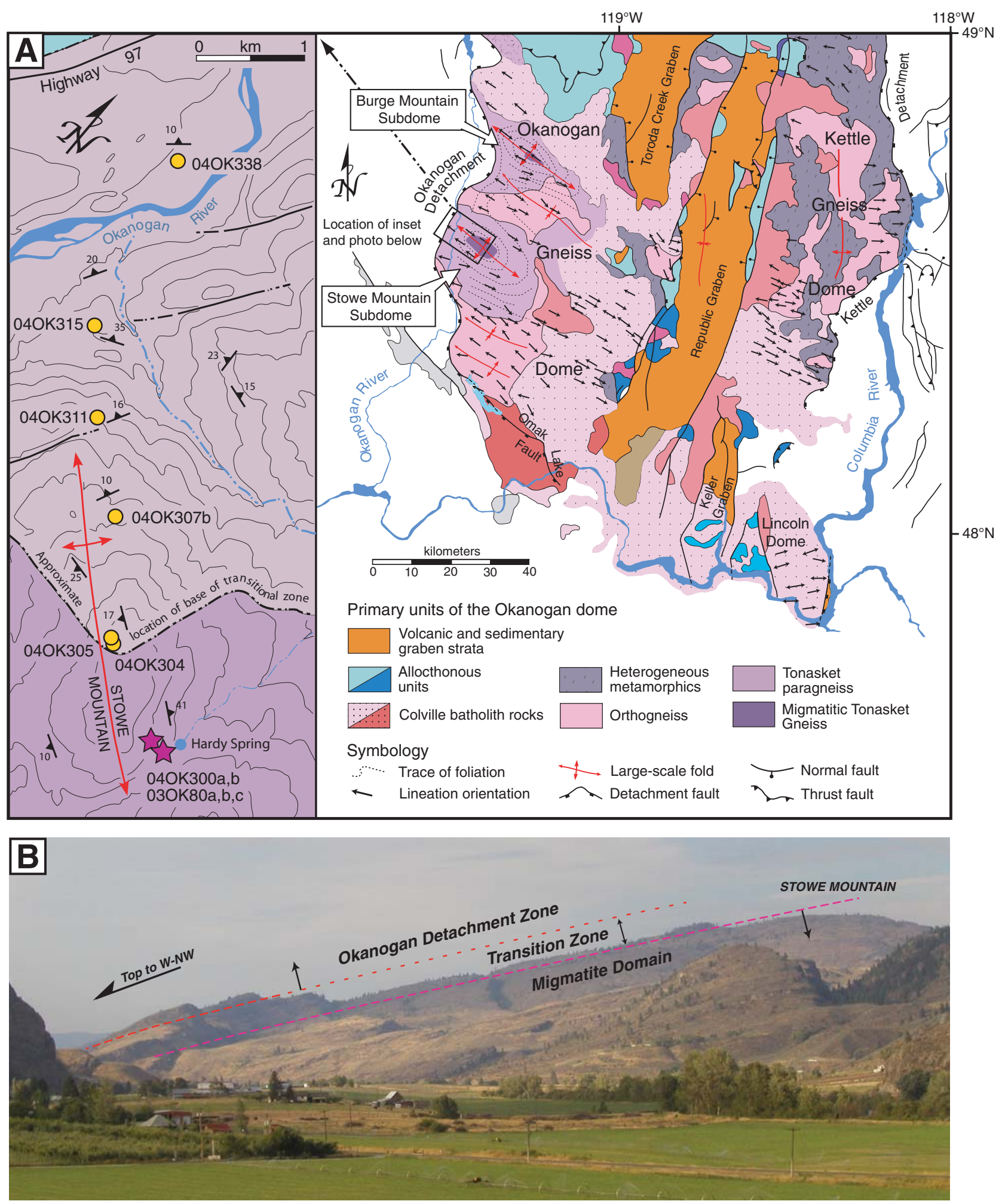

Figure 2. (A) Simplified geologic map of the Okanogan-Kettle dome region with inset showing location of study (lithologic contacts drawn after Holder and Holder, 1988, and references therein; Stoffel et al., 1991). Note similarity in fold axis orientation, lineation orientation, and orientation of en echelon graben in the Okanogan dome. Inset shows transect for $\mathrm{U}-\mathrm{Pb}$ and ${ }^{40} \mathrm{Ar} /{ }^{39} \mathrm{Ar}$ sampling near the Stowe Mountain subdome. Red arrows denote the axis of the Stowe Mountain subdome, purple stars are $\mathrm{U}-\mathrm{Pb}$ sample localities, and yellow circles are locations of ${ }^{40} \mathrm{Ar} /{ }^{39} \mathrm{Ar}$ samples. (B) Image of the western margin of the Okanogan dome as viewed to the north from south of Stowe Mountain along the Okanogan River. Image highlights the structural section along which samples were obtained from the migmatite domain, zone of transition, and the base of the Okanogan detachment zone. 

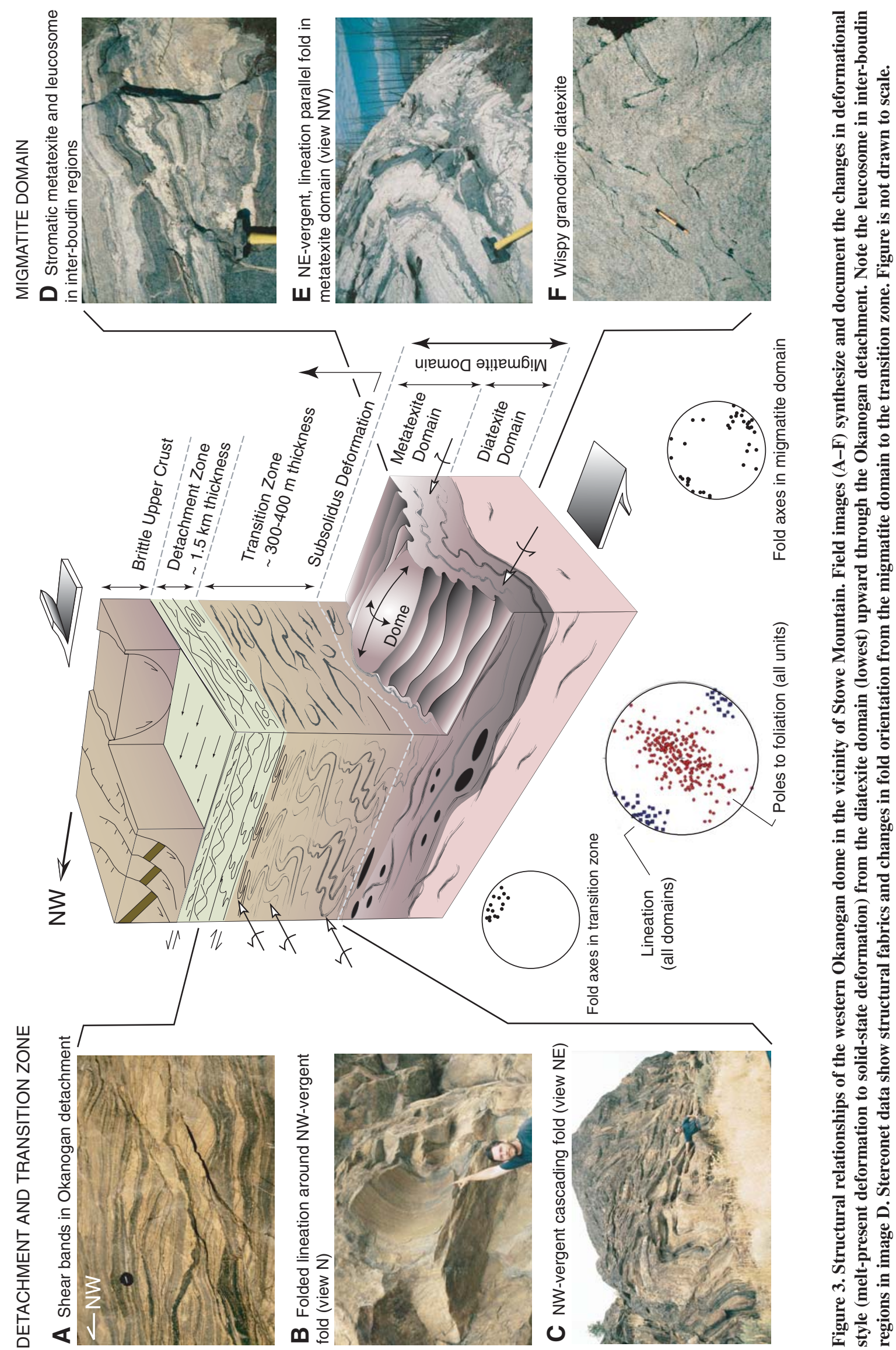
axes within the migmatitic Tonasket gneiss are dominantly oriented NW-SE and parallel the regional lineation preserved throughout much of the Okanogan dome and the extensional Okanogan Valley detachment fault ( $300^{\circ}$ orientation). Migmatitic lineation in the Tonasket gneiss is strong and defined by the preferred orientation of streaked biotite or hornblende selvages and elongate leucocratic lenses. Migmatitic lineation is also expressed within the migmatite domain as an $\mathrm{L}>\mathrm{S}$ gneissic fabric that is elongate parallel to both the extension direction inferred from boudin geometries in the migmatite domain and the regional stretching lineation (Fig. 3).

The migmatite domain on Stowe Mountain can broadly be divided into a structurally lower domain of diatexite and an overlying domain of metatexite (Fig. 3). Several lines of evidence indicate that deformation in both the diatexite and metatexite domains took place in the presence of melt: (1) outcrop-scale and petrographic relations suggest that leucosome layers are largely the product of in situ melt segregation (McLellan, 1988; Brown, 1994; Brown and Solar, 1998; Marchildon and Brown,
2002, 2003); (2) dilatancy sites such as shear bands are commonly filled with leucosome, and amphibolite layers boudinaged parallel to the stretching lineation show abundant leucosome in inter-boudin regions (Fig. 3D); and (3) overprinting relations indicate that leucosome layers are folded and cut by more leucosome that is variably deformed (Fig. 4).

Above the migmatite structural domain over a few hundred meters of structural thickness $(\sim 300-400 \mathrm{~m})$, structures that indicate the involvement of melt-present deformation in the Stowe Mountain migmatite domain show a dramatic change in deformation style, fold orientation, and vergence direction. Deformation within and above the transition zone affects the structural fabrics acquired in the lower migmatite domain but also records evidence for deformation under subsolidus conditions, as evidenced by crystal-plastic deformation of quartz and feldspar, asymmetric mica grains and porphyroclasts, and penetrative quartz stretching lineation. Fold axes in the transition zone trend N-NE, uniformly verge to the W-NW (parallel to the regional lineation), and fold the melt-present structural fabrics of the lower migmatite domain (e.g., folded migmatitic lineation and foliation, Figs. 3B and 3C).

Hansen and Goodge (1988) also recognized the change in fold axis orientation in the Tonasket gneiss in the SW Okanogan dome and attributed it to progressive reorientation during mylonitization of previously formed folds. In the vicinity of Stowe Mountain, our work documents a transition zone ( 300-400 m) between the structural fabrics in the migmatitic core and those of the detachment fault, expressed by the transition to solid-state deformation and cascading W-NW vergent folds. These folds decrease in amplitude and tighten progressively upward toward the base of the Okanogan Valley detachment mylonites (Fig. 3).

\section{Previous Geochronology}

There are few published geochronologic studies for the Okanogan dome, and the age of migmatite crystallization has not been previously determined. Previous estimates of the age of metamorphism are based on relative age relationships or are derived from tentative
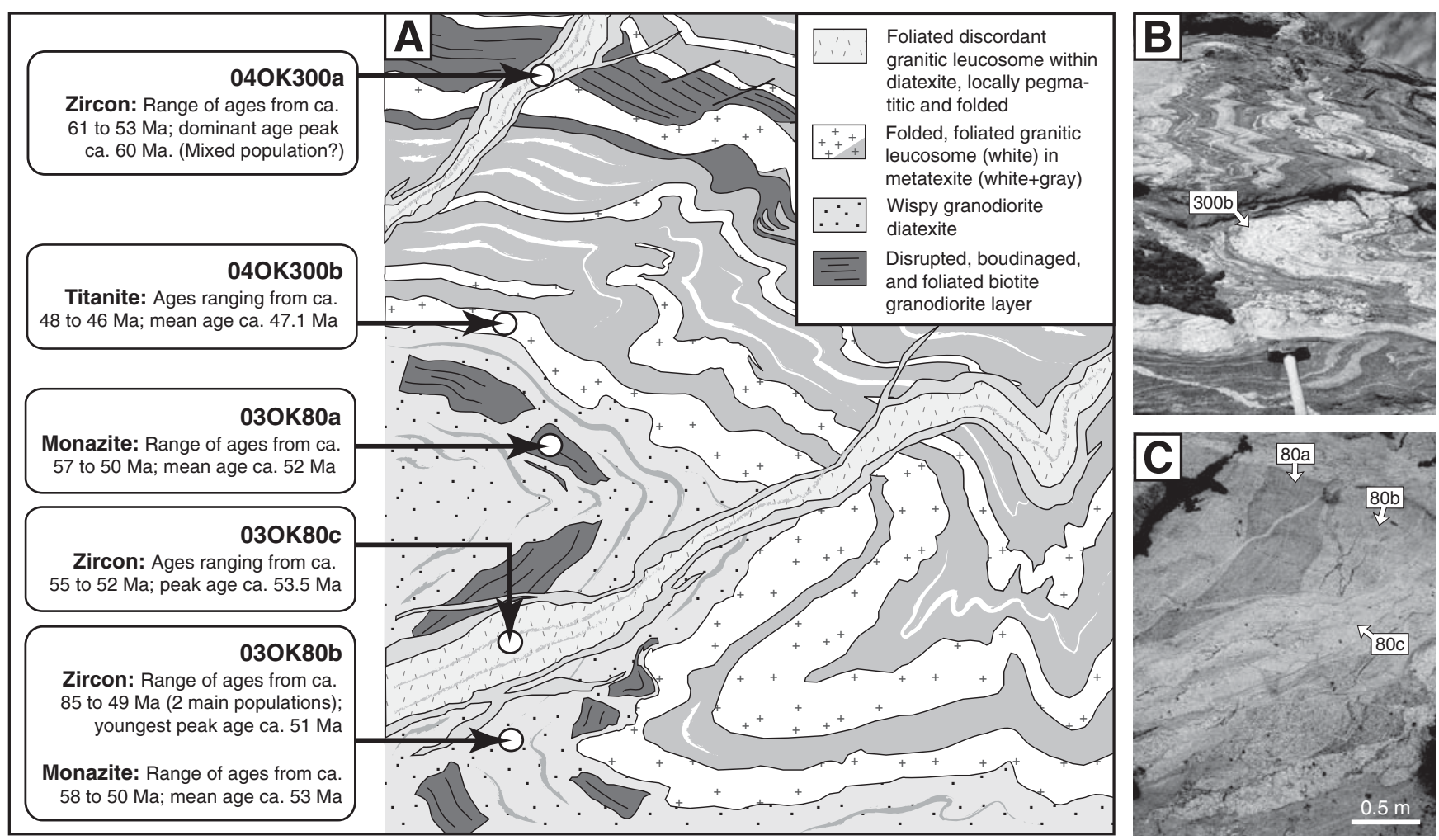

Figure 4. (A) Schematic drawing synthesizing leucosome relationships of sampled migmatite units on Stowe Mountain and summary of obtained sensitive high-resolution ion microprobe (SHRIMP) ages. Figure combines field relationships observed over $\sim 150 \mathrm{~m}$ of structural thickness within the migmatite domain. (B) Folded and foliated stromatic metatexite with arrow pointing to granitic leucosome of sample 04OK300b. (C) Diatexite gneiss and outcrop sampling locality of samples 030K80a, 03OK80b, and 03OK80c showing the crosscutting relationships of these various phases and sampled layering at this locality. Sample 040K300a is not shown on field photographs but shares field relationships similar to sample $030 \mathrm{K80} \mathrm{c}$ but within the metatexite domain. 
correlations with rocks in the Shuswap metamorphic core complex in British Columbia. Based on dated post-metamorphic plutonic rocks and syntectonic plutons, peak metamorphism is interpreted to have occurred in Jurassic to Early Cretaceous time (Armstrong, 1982; Archibald et al., 1983). Fox et al. (1976) reported $\mathrm{U}-\mathrm{Pb}$ ages of $100 \mathrm{Ma}$ and $87.3 \mathrm{Ma}$ for zircons from upper amphibolite facies rocks of the northern Tonasket gneiss. These ages were interpreted as either the maximum time since crystallization, or the age of metamorphism resulting in radiogenic $\mathrm{Pb}$ loss. $\mathrm{K}$-Ar ages were obtained from the youngest intrusive suite, the Colville batholith (Fig. 2); these cooling ages range between 53 and $45 \mathrm{Ma}$. Nearly all the plutonic rocks of the Okanogan complex were emplaced prior to, and are affected by, mylonitic deformation.

Bounding faults of the Republic graben cut the intrusive suite and some zones of mylonitic deformation (Fox et al., 1976, 1977; Pearson and Obradovich, 1977; Parkinson, 1985; Tempelman-Kluit and Parkinson, 1986; Holder and Holder, 1988; Carlson and Moye, 1990; Box and Wooden, 1994). Basin fill of the Toroda Creek and Republic graben is dated at ca. 54 to $48 \mathrm{Ma}$ (Pearson and Obradovich, 1977; Atwater, 1985; Suydam and Gaylord, 1997), and therefore intrusion of the Colville batholith, mylonitic deformation, cooling and exhumation, and reburial beneath the basin fill took place in a relatively short time interval.

The age of partial melting in the Okanogan dome is unknown, and therefore important relationships between partial melting (migmatization), dome development, and extension are unresolved. We present new data that bracket the timing of crystallization and cooling of partially molten crust during different stages of deformation in the tectonic evolution of the Okanogan dome.

\section{SAMPLING METHODOLOGY AND SAMPLE DESCRIPTIONS}

\section{U-Pb Samples}

Sampling for $\mathrm{U}-\mathrm{Pb}$ isotopic analysis focused on migmatite exposed on eastern Stowe Mountain where structural evidence indicates that deformation took place in the presence of melt (McLellan, 1988; Brown, 1994; Brown and Solar, 1998; Marchildon and Brown, 2002, 2003). Five U-Pb samples were selected from folded, boudinaged, and crosscutting leucosome layers within both diatexite and metatexite domains where their relationships could be tied to specific structural characteristics of the Okanogan dome (Fig. 4).
Diatexite of the lowermost migmatite domain is fine grained and granodioritic, and migmatitic textures are dominated by wispy schlieren-like structures defined by alternating quartzofeldspathic layers and biotite selvages. Boudinaged layers of stromatic migmatite, amphibolite, calc-silicate, and other gneiss are also common, forming rafts (schollen texture) within leucosome-rich bodies (Fig. 4C; e.g., 80a). Three samples of diatexite were collected from a large outcrop just SW of Hardy Spring on eastern Stowe Mountain (Figs. 2A and 4C). Samples 03OK80a and 03OK80b were collected from the most abundant and characteristic phases of diatexite observed. Sample 03OK80a is from a discontinuous layer of stromatic, biotite granodiorite migmatite that contains a well-developed migmatitic foliation (Figs. 4A and 4C). This layer is boudinaged within a more leucocratic granodiorite diatexite containing wispy biotite selvages (sample 03OK80b; Figs. 4A and 4C). Sample 03OK80c is from a discordant granitic leucosome that cuts across structural fabrics in diatexite samples 03OK80a and 03OK80b but may also be foliated and folded with these units when followed parallel to layering (Figs. 4A and 4C). Based on crosscutting field relationships, 03OK80c is the youngest leucosome phase sampled at this locality (Figs. 4A and 4C). All samples were separated for zircon, monazite, and titanite; sample $03 \mathrm{OK} 80 \mathrm{a}$ yielded monazite, both zircon and monazite were present in sample 03OK80b, and 03OK80c yielded only zircon.

Two samples, 04OK300a and 04OK300b, were collected from an outcrop in the metatexite domain structurally above the diatexite at locality 03OK80. Sample 04OK300b (Figs. 4A and $4 \mathrm{~B}$ ) is from a parasitically folded leucosome layer within a large fold with a lineation-parallel fold hinge $\left(280^{\circ}\right.$ orientation) characteristic of the folding style in the migmatite domain at Stowe Mountain. Sample 04OK300a is from a weakly foliated discordant leucosome layer that, like sample $03 \mathrm{OK} 80 \mathrm{c}$, cuts the folded migmatite leucosome layers at a high angle but also becomes folded and foliated itself when followed along its outcrop trace (Fig. 4A). Sample 04OK300a and sample 03OK80c, though from different parts of the migmatite domain, show the same structural relationships and are compositionally similar. Sample 04OK300a yielded zircon, and sample 04OK300b contained no zircon but had abundant titanite.

\section{${ }^{40} \mathrm{Ar} /{ }^{\beta 9} \mathrm{Ar}$ Samples}

Samples for ${ }^{40} \mathrm{Ar} /{ }^{39} \mathrm{Ar}$ analysis were collected on a transect $\sim 6 \mathrm{~km}$ long, extending from eastern Stowe Mountain NW toward the western margin of the Okanogan dome (Fig. 2). Samples were collected on a map spacing of $\sim 1 \mathrm{~km}$ covering an approximate structural thickness of $1.5 \mathrm{~km}$. This transect extends structurally upward from diatexite exposed in the deepest structural levels through migmatitic paragneiss and biotite \pm hornblende quartzofeldspathic gneiss to the Okanogan Valley detachment fault.

\section{U-Pb GEOCHRONOLOGY}

Results of $\mathrm{U}-\mathrm{Pb}$ analyses are reported in the GSA Data Repository (Tables DR1-3)1. Analytical methods for geochronology are described in the supplementary material in the Data Repository.

\section{Zircon}

\section{Granodioritic Diatexite (03OK80b)}

Zircon crystals in sample $03 \mathrm{OK} 80 \mathrm{~b}$ are characterized by euhedral to subhedral grains, typically $100-500 \mu \mathrm{m}$ in length. Zircons commonly form elongate di-pyramidal crystals with length to width ratios $>3: 1$. When viewed in transmitted light, zircon grains are clear and rarely contain visible inclusions or cracks. Under cathodoluminescence (CL), grains have varying internal structure but typically display sector and oscillatory-zoned euhedral to subhedral core domains surrounded by rim overgrowths (Fig. 5A). A small number of grains have less defined or complexly zoned cores that contain highly luminescent anhedral cores also surrounded by oscillatory-zoned domains (e.g., grain 17, Fig. 5A). Overgrowths on cores are common and display great variation in their thickness and luminescence and range from finely zoned rims to homogeneous rims or tips (Fig. 5A).

We analyzed 28 zircon grains with 37 individual spot analyses in sample 03OK80b. Analyses were selected in both core and rim domains of grains with variable internal structure. The zircon population of sample $03 \mathrm{OK} 80 \mathrm{~b}$ yielded the widest range of ${ }^{206} \mathrm{~Pb} /{ }^{238} \mathrm{U}$ ages of all the zircon samples analyzed. The majority of analyses $(\mathrm{N}=24)$ have Late Cretaceous ${ }^{206} \mathrm{~Pb} /{ }^{238} \mathrm{U}$ ages for both core and rim domains, defining a broad group of ages from ca. 85 to $70 \mathrm{Ma}$ (Figs. 5B and 5C, Table $\mathrm{DR} 1)$. A second distinct group of ${ }^{206} \mathrm{~Pb} /{ }^{238} \mathrm{U}$ ages, ranging from ca. 57 to $49 \mathrm{Ma}$ (Figs. 5B and 5C, Table DR1), was obtained from 13 analytical spots. These Paleocene-Eocene ages occur both in zircon cores and rims (e.g., grains 1 and 4; Fig. 5A). The Paleocene-Eocene ${ }^{206} \mathrm{~Pb} /{ }^{238} \mathrm{U}$ ages define two sub-peaks, one centered at ca. $55 \mathrm{Ma}$

${ }^{1}$ GSA Data Repository Item 2008079, Tables DR1-4 and analytical methods, is available at www. geosociety.org/pubs/ft2008.htm. Requests may also be sent to editing@geosociety.org. 

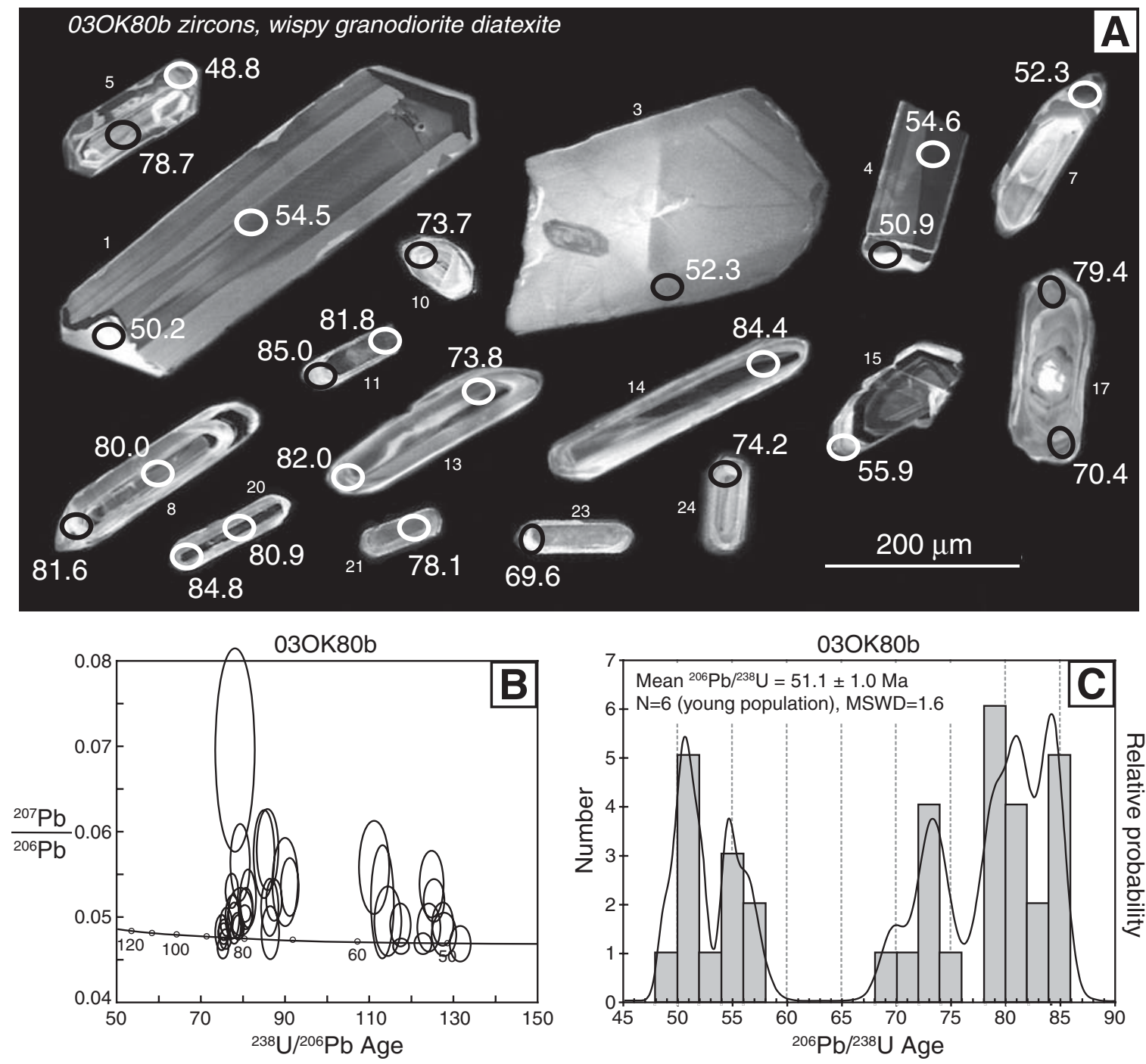

Figure 5. (A) Cathodoluminescence images of representative zircon grains dated using the sensitive high-resolution ion microprobe (SHRIMP) for sample $030 \mathrm{K80b}$ (wispy granodiorite diatexite). Small numbers (1-24) refer to grain number designations in Table DR1. Larger numbers are ${ }^{206} \mathrm{~Pb} /{ }^{238} \mathrm{U}$ ages in Ma for individual spot analyses (see Table DR1 for corresponding error on spot analyses). (B) Tera-Wasserburg concordia diagram of the calibrated total ${ }^{238} \mathrm{U} /{ }^{206} \mathrm{~Pb}$ ratios versus the total ${ }^{207} \mathrm{~Pb} /{ }^{206} \mathrm{~Pb}$ ratio for zircon sample $030 \mathrm{~K} 80 \mathrm{~b}$. Analyses plotted as one sigma error ellipses. (C) Probability density plots with stacked histogram for zircon sample 03OK80b; the weighted mean ${ }^{206} \mathrm{~Pb} /{ }^{238} \mathrm{U}$ age calculation and uncertainty is given at $95 \%$ confidence limits and includes the uncertainty in the $\mathrm{U} / \mathrm{Pb}$ ratio calibration of the reference zircon. Plots and calculations based on Isoplot of Ludwig (2003).

(Fig. 5C), and a second well-defined sub-peak of six analyses yields the youngest mean ${ }^{206} \mathrm{~Pb} /{ }^{238} \mathrm{U}$ age of $51.1 \pm 1.0 \mathrm{Ma}$ (mean square of weighted deviates $[\mathrm{MSWD}]=1.6)$ for this sample.

\section{Discordant Granitic Leucosome in Diatexite (03OK80c)}

The zircon population in sample $03 \mathrm{OK} 80 \mathrm{c}$ consists largely of inclusion-free euhedral grains that form elongate to equant crystals with lengths typically $200-300 \mu \mathrm{m}$. Zircon grains have simi- lar degrees of luminescence under CL and have well-defined oscillatory and sector-zoned magmatic cores (Fig. 6A). Unzoned zircon grains are visible in CL and commonly display a thin $(<20$ $\mu \mathrm{m})$, highly luminescent rim at their margin.

A total of 19 zircon grains was analyzed from 20 total areas in sample 03OK80c. Nineteen of the 20 analyzed spots give ${ }^{206} \mathrm{~Pb} /{ }^{238} \mathrm{U}$ ages ranging from ca. 55 to $52 \mathrm{Ma}$ for both core and rim analyses (e.g., grain 1, Fig. 6A; Table DR1). These analyses define a simple relative probabil- ity distribution (Fig. 6C) with a weighted mean for all 19 analyses of $53.7 \pm 0.6 \mathrm{Ma}$ (MSWD $=2.0$ ). Eliminating analyses $6.1,9.1,10.1$, and 16.1, which fall more than 3 sigma from the mean, results in a weighted mean age of 53.5 $\pm 0.5 \mathrm{Ma}(\mathrm{MSWD}=1.1$, Fig. 6C). Only one analysis (7.1, Table DR1) had an age outside of the main distribution, yielding a ${ }^{206} \mathrm{~Pb} /{ }^{238} \mathrm{U}$ age of ca. $76 \mathrm{Ma}$. This age is similar to Late Cretaceous ages for zircon in the older population of sample $03 \mathrm{OK} 80 \mathrm{~b}$. 

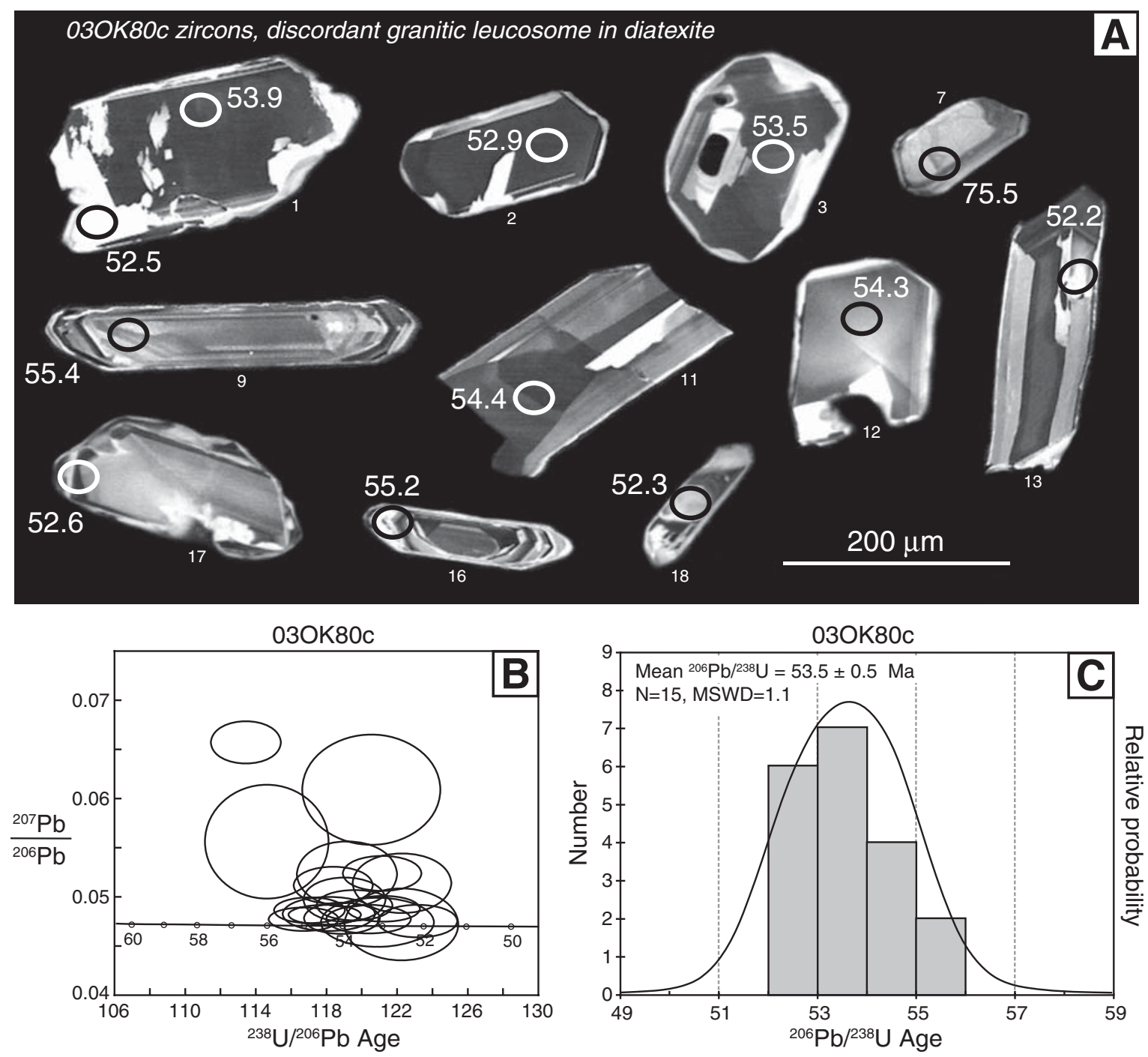

Figure 6. (A) Cathodoluminescence images of representative zircon grains dated using the sensitive high-resolution ion microprobe (SHRIMP) for sample 03OK80c (discordant granitic leucosome in diatexite). Small numbers (1-18) refer to grain number designations in Table DR1. Larger numbers are ${ }^{206} \mathrm{~Pb} /{ }^{238} \mathrm{U}$ ages in Ma for individual spot analyses (see Table DR1 for corresponding error on spot analyses). (B) Tera-Wasserburg concordia diagram of the calibrated total ${ }^{238} \mathrm{U} /{ }^{06} \mathrm{~Pb}$ ratios versus the total ${ }^{207} \mathrm{~Pb} /{ }^{06} \mathrm{~Pb}$ ratio for zircon sample $03 \mathrm{OK} 80 \mathrm{c}$. Analyses plotted as one sigma error ellipses. (C) Probability density plots with stacked histogram for zircon sample 03OK80c; the weighted mean ${ }^{206} \mathrm{~Pb} /{ }^{338} \mathrm{U}$ age calculation and uncertainty is given at $95 \%$ confidence limits and includes the uncertainty in the $\mathrm{U} / \mathrm{Pb}$ ratio calibration of the reference zircon. Plots and calculations based on Isoplot of Ludwig (2003).

\section{Discordant Granitic Leucosome in Metatexite (04OK300a)}

Zircon grains in sample 04OK300a contain more abundant inclusion trails and a higher density of microcracks than zircon in diatexite. Grains are clear, euhedral to subhedral, and range in size from 50 to $400 \mu \mathrm{m}$. Zircons range from unzoned to irregularly zoned (Fig. 7A). Ten- to $60-\mu \mathrm{m}$-thick euhedralovergrowths on complexlyzonedcores are common.
In this sample, a total of 20 areas on 20 grains were analyzed. Despite the apparent internal complexity revealed in CL, the majority of rim analyses and all 11 cores analyzed gave Paleocene ${ }^{206} \mathrm{~Pb} /{ }^{238} \mathrm{U}$ ages from ca. 61 to $58 \mathrm{Ma}$ (Table DR1). Four rim analyses (13.1 16.1, 17.1, and 18.1; Table DR1) yielded ${ }^{206} \mathrm{~Pb} /{ }^{238} \mathrm{U}$ ages extending into Eocene time and are younger than the dominant age peak (Fig. 7C). Three of the four analyses recording younger ${ }^{206} \mathrm{~Pb} /{ }^{238} \mathrm{U}$ ages are located on distinct tips and rims (grains 13, 16, and 18;
Fig. 7A). When these four analyses, which are more than 3 sigma from the mean, are excluded, the weighted mean age of the remaining 16 analyses is $59.8 \pm 0.5 \mathrm{Ma}(\mathrm{MSWD}=1.2$, Fig. $7 \mathrm{C})$.

\section{Monazite}

\section{Biotite Granodiorite Layer in Diatexite (03OK80a)}

Monazite grains obtained from sample 03OK80a are typically brown to honey-colored 

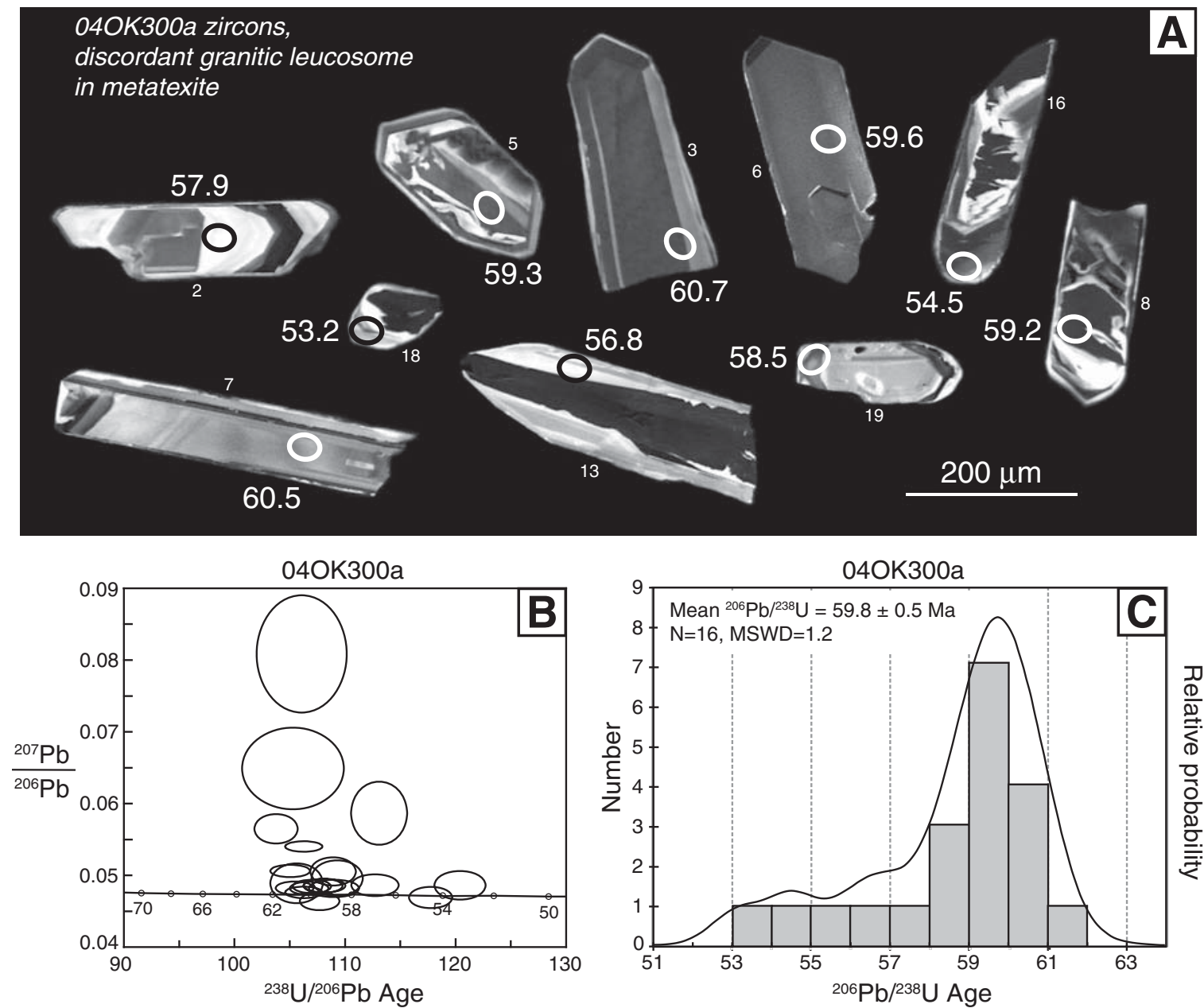

Figure 7. (A) Cathodoluminescence images of representative zircon grains dated using the sensitive high-resolution ion microprobe (SHRIMP) for sample 040K300a (discordant granitic leucosome in metatexite). Small numbers (2-19) refer to grain number designations in Table DR1. Larger numbers are ${ }^{206} \mathrm{~Pb} /{ }^{238} \mathrm{U}$ ages in Ma for individual spot analyses (see Table DR1 for corresponding error on spot analyses). (B) Tera-Wasserburg concordia diagram of the calibrated total ${ }^{238} \mathrm{U} /{ }^{206} \mathrm{~Pb}$ ratios versus the total ${ }^{207} \mathrm{~Pb} /{ }^{206} \mathrm{~Pb}$ ratio for zircon sample $040 \mathrm{OK300a}$. Analyses plotted as one sigma error ellipses. (C) Probability density plots with stacked histogram for zircon sample 040K300a; the weighted mean ${ }^{206} \mathrm{~Pb} /{ }^{238} \mathrm{U}$ age calculation and uncertainty is given at $95 \%$ confidence limits and includes the uncertainty in the $\mathrm{U} / \mathrm{Pb}$ ratio calibration of the reference zircon. Plots and calculations based on Isoplot of Ludwig (2003).

grains when viewed in transmitted light, and are relatively uniform in size $(150-200 \mu \mathrm{m})$. Most grains are equant and anhedral to subhedral in shape with rare, well-formed euhedral crystals. Back-scattered electron (BSE) images of monazite show a dominantly unzoned population of grains with a subordinate number displaying sector zoning (e.g., grains 5 and 18, Fig. 8A).

Eighteen monazite grains were analyzed for a total of 21 analyses. The majority of analyses $(\mathrm{N}=19)$ yield Eocene ${ }^{206} \mathrm{~Pb} /{ }^{238} \mathrm{U}$ ages ranging from ca. 57 to $50 \mathrm{Ma}$ (Figs. 8B and 8C; Table DR2) and show no correlation to zoned domains (where present) or location in monazite grains. Two analyses give Paleocene ${ }^{206} \mathrm{~Pb} /{ }^{238} \mathrm{U}$ ages and are older than the main cluster of uncorrected ages on the Tera-Wasserburg diagram (Fig. 8B). The range of monazite ${ }^{206} \mathrm{~Pb} /{ }^{238} \mathrm{U}$ ages spans $\sim 7$ m.y., and the dominant group $(\mathrm{N}=14)$ yields a weighted mean age of $52.0 \pm 0.6 \mathrm{Ma}$ (MSWD $=0.8$, Fig. $8 \mathrm{C}$ ).

\section{Granodioritic Diatexite (03OK80b)}

Sample 03OK80b is the only sample that yielded both zircon and monazite. Monazite grains are commonly subhedral and form 200-400 $\mu \mathrm{m}$ equant grains of light honey color. Monazite grains in sample $03 \mathrm{OK} 80 \mathrm{~b}$ contrast those in 03OK80a and typically have less erratic shapes with better defined crystal faces. Additionally, BSE imaging shows that monazite grains characteristically have a zoned internal structure in sample 03OK80b. Sector and symmetric growth zoning are typical with a subordinate number of grains displaying complex or embayed zonation in their cores (Fig. 9A). Overgrowths are common and typically occur as $30-100 \mu \mathrm{m}$ homogeneous rims that appear brighter in BSE images (e.g., grains, 12, 15, and 16, Fig. 9A).

Twenty locations on 18 monazite grains were analyzed, yielding ${ }^{206} \mathrm{~Pb} /{ }^{238} \mathrm{U}$ ages from ca. 58 to $50 \mathrm{Ma}$ and are similar to ${ }^{206} \mathrm{~Pb} /{ }^{238} \mathrm{U}$ monazite ages obtained from sample 03OK80a (Table DR2). Four analyses gave older Paleocene ${ }^{206} \mathrm{~Pb} /{ }^{238} \mathrm{U}$ ages from ca. 58 to $56 \mathrm{Ma}$ and are older than the main cluster of uncorrected analyses on the Tera-Wasserburg plot 

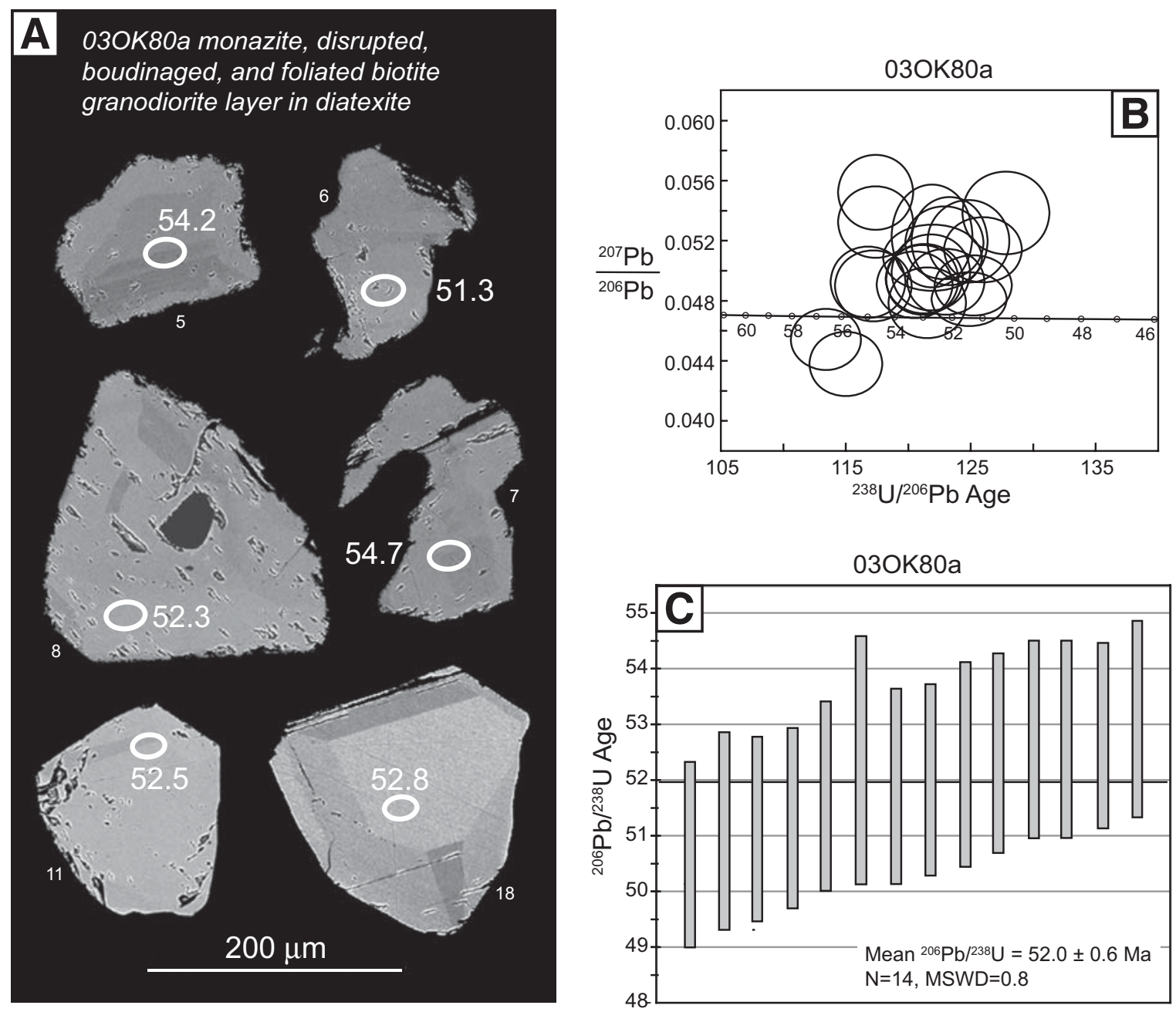

Figure 8. (A) Back-scattered electron (BSE) images of representative monazite grains dated using the sensitive high-resolution ion microprobe (SHRIMP) for sample 03OK80a (disrupted, boudinaged, and foliated biotite granodiorite layer in diatexite). Small numbers (5-18) refer to grain number designations in Table DR2. Larger numbers are ${ }^{206} \mathrm{~Pb} /{ }^{238} \mathrm{U}$ ages in Ma for individual spot analyses (see Table DR2 for corresponding error on spot analyses). (B) Tera-Wasserburg concordia diagram of the calibrated total ${ }^{238} \mathrm{U} /{ }^{206} \mathrm{~Pb}$ ratios versus the total ${ }^{207} \mathrm{~Pb} /{ }^{206} \mathrm{~Pb}$ ratio for monazite sample 03OK80a. Analyses plotted as one sigma error ellipses. (C) Weighted average age plot from monazite sample $030 \mathrm{~K} 80 \mathrm{a}$; the weighted mean ${ }^{206} \mathrm{~Pb} /{ }^{238} \mathrm{U}$ age calculation and uncertainty is given at $95 \%$ confidence limits and includes the uncertainty in the $\mathrm{U} / \mathrm{Pb}$ ratio calibration of the reference monazite. Plots and calculations based on Isoplot of Ludwig (2003).

of Figure 9B. The bulk of analyses $(\mathrm{N}=16)$ yield Eocene ${ }^{206} \mathrm{~Pb} /{ }^{238} \mathrm{U}$ ages from ca. 54 to $50 \mathrm{Ma}$ (Fig. 9C) and have a weighted mean age of $52.3 \pm 0.8 \mathrm{Ma}(\mathrm{MSWD}=2.2)$ for all 16 spots. Excluding the three youngest analyses $(6.1,9.1$, and 15.1, Table DR2), which fall more than 3 sigma from the mean, results in a weighted mean age of $52.9 \pm 0.6 \mathrm{Ma}$ and a lower MSWD of 0.8 .

\section{Titanite}

Titanite grains from sample 04OK300b, a folded and foliated granitic leucosome from a metatexite, are clear to transparent and anhedral (Fig. 10A), with only minor inclusions and cracks. In BSE images, titanite displays dramatic zoning characterized in some grains by a bright rim of varying width around a darker core. The core domain in some grains is homogeneous and in others displays euhedral growth zoning (Fig. 10A). Some grains also show embayed rim and core relationships (e.g., grain 8, Fig. 10A).

We analyzed both rim and core domains of 15 grains for a total of 18 analyses (Table DR3). All analyzed spots gave Eocene ${ }^{206} \mathrm{~Pb} /{ }^{238} \mathrm{U}$ ages ranging from ca. 48 to $46 \mathrm{Ma}$ for core and rim analyses. These analyses define a simple distribution (Fig. 10C) with a weighted mean for all 18 analyses of $47.1 \pm 0.5 \mathrm{Ma}(\mathrm{MSWD}=0.6$, Fig. 10C).

\section{BIOTITE ${ }^{40} \mathrm{Ar}-{ }^{39} \mathrm{Ar}$ THERMOCHRONOLOGY}

Results of Ar-Ar analyses are reported in the GSA Data Repository (Table DR4; see footnote 1) and a summary of Ar-Ar age determinations is reported in Table 1. Analytical methods for thermochronology are described in the supplementary material in the Data Repository. 

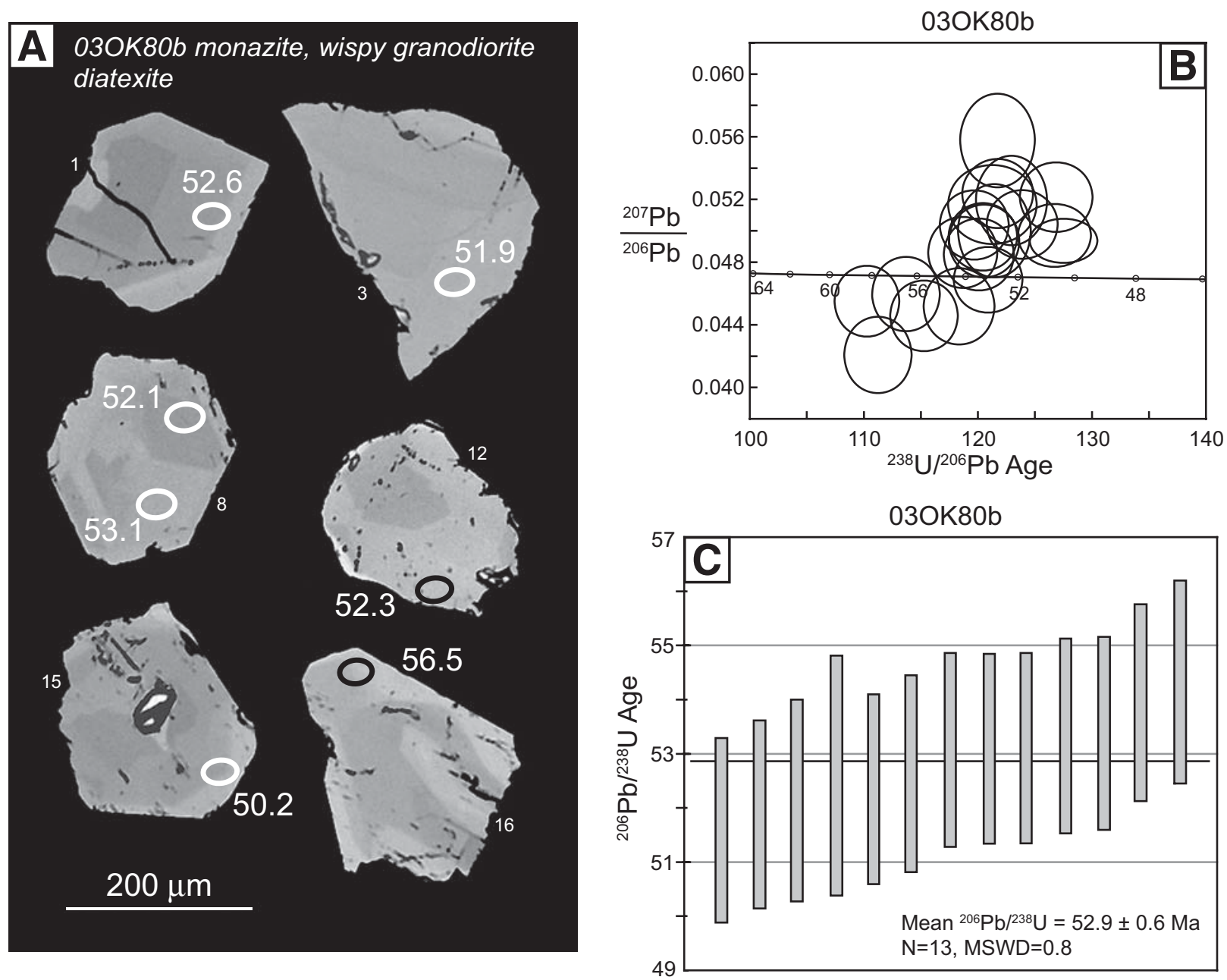

Figure 9. (A) Back-scattered electron (BSE) images of representative monazite grains dated using the sensitive high-resolution ion microprobe (SHRIMP) for sample 03OK80b (wispy granodiorite diatexite). Small numbers (1-16) refer to grain number designations in Table DR2. Larger numbers are ${ }^{206} \mathrm{~Pb} /{ }^{238} \mathrm{U}$ ages in Ma for individual spot analyses (see Table DR2 for corresponding error on spot analyses). (B) Tera-Wasserburg concordia diagram of the calibrated total ${ }^{238} \mathrm{U} /{ }^{206} \mathrm{~Pb}$ ratios versus the total ${ }^{207} \mathrm{~Pb} /{ }^{06} \mathrm{~Pb}$ ratio for monazite sample 03OK80b. Analyses plotted as one sigma error ellipses. (C) Weighted average age plot from monazite sample $030 \mathrm{K80b}$; the weighted mean ${ }^{206} \mathrm{~Pb} /{ }^{238} \mathrm{U}$ age calculation and uncertainty is given at 95\% confidence limits and includes the uncertainty in the U/Pb ratio calibration of the reference monazite. Plots and calculations based on Isoplot of Ludwig (2003)

Samples with Unaltered Biotite (040K305, 040K307b, and 040K338)

Biotite grains in this group of samples (04OK305, 04OK307b, and 04OK338) are dominantly unaltered, dark brown, and range in size from $<50 \mu \mathrm{m}$ to $>750 \mu \mathrm{m}$. These samples yield the least discordant ages of the samples analyzed, and plateau-like segments for a significant number of steps characterize the stepwise heating and release of argon.

Sample 04OK305 yielded the most discordant ages within this group. Total release of Ar for sample 04OK305 was achieved over 14 step-heating intervals from 570 to $1120^{\circ} \mathrm{C}$.
Ages for individual heating steps range from ca. 48 to $26 \mathrm{Ma}$ and give an integrated age of $44.7 \pm 0.5 \mathrm{Ma}$ (Table 1, Table DR4). Results for sample 04OK305 exhibit a plateau-like pattern over steps 5-8, and ages range from ca. 48 to $46 \mathrm{Ma}$ (Fig. 11A). Using size of step weighting, the calculated age for this section of the age spectrum is $47.1 \pm 0.2 \mathrm{Ma}$ for $61.9 \%$ of the gas released (Fig. 11A, Table 1). Younger ages are evolved in the early gas release, with monotonically rising ages until the plateau-like section is reached. An inverse isochron analysis of all 14 step-heating analyses yields an intercept age of $47.9 \pm 0.1 \mathrm{Ma}$ $(1 \sigma$, MSWD $=8.4$; Fig. 11A $)$. Despite the high MSWD from the isochron reduction, the 47.9 Ma isochron age is our preferred age for this sample (Table 1).

Fourteen step-heating analyses, from $\mathrm{T}=$ $570-1060{ }^{\circ} \mathrm{C}$, resulted in total release of $\mathrm{Ar}$ from biotite sample $040 K 307 \mathrm{~b}$. Individual step intervals gave ages of ca. 51 to $43 \mathrm{Ma}$ with an integrated age of $47.7 \pm 0.4 \mathrm{Ma}$ (Table 1 , Table DR4). The age spectrum defines a large plateaulike section defined by steps $4-8$, yielding an age of $47.9 \pm 0.2 \mathrm{Ma}$ over $83.0 \%$ of the gas evolved (Fig. 11B, Table 1). Inverse isochron analysis of all 14 steps defines an intercept age of 47.9 $\pm 0.1 \mathrm{Ma}(1 \sigma, \mathrm{MSWD}=3.4$; Fig. $11 \mathrm{~B})$, identical to the age obtained from the plateau-like seg- 

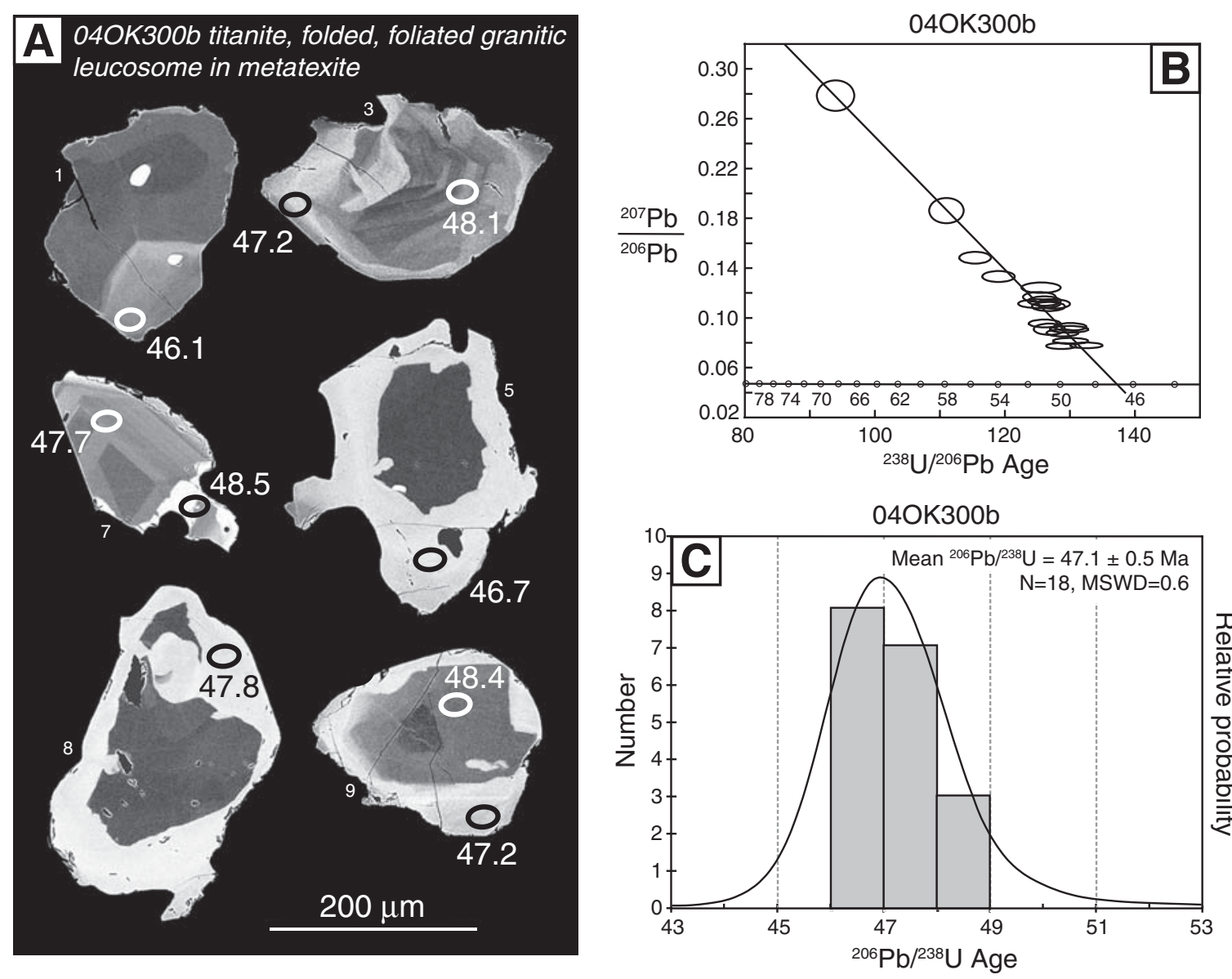

Figure 10. (A) Back-scattered electron (BSE) images of representative titanite grains dated using the sensitive highresolution ion microprobe (SHRIMP) for sample 040K300b (folded, foliated granitic leucosome in metatexite). Small numbers (1-9) refer to grain number designations in Table DR3. Larger numbers are ${ }^{206} \mathrm{~Pb} /{ }^{238} \mathrm{U}$ ages in $\mathrm{Ma}$ for individual spot analyses (see Table DR3 for corresponding error on spot analyses). (B) Tera-Wasserburg concordia diagram of the calibrated total ${ }^{238} \mathrm{U} /{ }^{206} \mathrm{~Pb}$ ratios versus the total ${ }^{207} \mathrm{~Pb} /{ }^{206} \mathrm{~Pb}$ ratio for titanite sample $04 \mathrm{OK} 300 \mathrm{~b}$. Analyses plotted as one sigma error ellipses. The 3-D linear regression line is shown from the measured ${ }^{204} \mathrm{~Pb} /{ }^{206} \mathrm{~Pb}$ ratio for each analysis along with total ${ }^{207} \mathrm{~Pb} /{ }^{206} \mathrm{~Pb}$ and ${ }^{238} \mathrm{U} /{ }^{206} \mathrm{~Pb}$ ratios to define a lower concordia intercept of 47.0 \pm 0.5 Ma (mean square weighted deviate $[\mathrm{MSWD}]=1.0$ ). (C) Probability density plots with stacked histogram for titanite sample $040 \mathrm{~K} 300 \mathrm{~b}$; the weighted mean ${ }^{206} \mathrm{~Pb} /{ }^{238} \mathrm{U}$ age calculation and uncertainty is given at $95 \%$ confidence limits and includes the uncertainty in the $\mathrm{U} / \mathrm{Pb}$ ratio calibration of the reference titanite. Plots and calculations based on Isoplot of Ludwig (2003).

TABLE 1. SUMMARY OF AR-AR AGE DETERMINATIONS FOR BIOTITE SAMPLES

\begin{tabular}{|c|c|c|c|c|c|c|}
\hline \multirow[t]{2}{*}{ Sample } & \multirow[t]{2}{*}{ Location } & \multirow[t]{2}{*}{ Preferred age } & \multicolumn{3}{|c|}{ Isochron method } & \multirow[t]{2}{*}{ Integrated age } \\
\hline & & & Age & Y-intercept $\mathrm{Ar}^{40} / \mathrm{Ar}^{36}$ & MSWD & \\
\hline $040 K 305$ & $N 48^{\circ} 36.31^{\prime}, W 119^{\circ} 25.92^{\prime}$ & $47.9 \pm 0.1 \mathrm{Ma}$ (steps 5-8) & $47.9 \pm 0.1 \mathrm{Ma}$ & $258.9 \pm 1.6$ & 8.37 & $44.7 \pm 0.5 \mathrm{Ma}$ \\
\hline 04OK307b & $N 48^{\circ} 36.75^{\prime}, W 119^{\circ} 26.48^{\prime}$ & $47.9 \pm 0.2 \mathrm{Ma}$ (steps 4-8) & $47.9 \pm 0.1 \mathrm{Ma}$ & $289.8 \pm 2.6$ & 3.38 & $47.7 \pm 0.4 \mathrm{Ma}$ \\
\hline 04ОК338 & $N 48^{\circ} 38.19^{\prime}, W 119^{\circ} 27.84^{\prime}$ & $48.0 \pm 0.1 \mathrm{Ma}$ (steps $2-14$ ) & $48.0 \pm 0.1 \mathrm{Ma}$ & $293.2 \pm 3.4$ & 2.11 & $47.9 \pm 0.7 \mathrm{Ma}$ \\
\hline $040 К 304$ & $N 48^{\circ} 36.30^{\prime}, W 119^{\circ} 25.87^{\prime}$ & - & $45.2 \pm 0.1 \mathrm{Ma}$ & $233.6 \pm 1.8$ & 15.72 & $28.0 \pm 0.8 \mathrm{Ma}$ \\
\hline 04OK311 & $N 48^{\circ} 37.04^{\prime}, W 119^{\circ} 27.04^{\prime}$ & - & $44.8 \pm 0.1 \mathrm{Ma}$ & $257.5 \pm 1.3$ & 38.73 & $38.7 \pm 0.7 \mathrm{Ma}$ \\
\hline $04 \mathrm{OK} 315$ & $N 48^{\circ} 37.35^{\prime}, W 119^{\circ} 27.49^{\prime}$ & - & $44.0 \pm 0.2 \mathrm{Ma}$ & $241.9 \pm 1.7$ & 62.13 & $34.9 \pm 0.6 \mathrm{Ma}$ \\
\hline
\end{tabular}

ment. Our preferred age for sample 04OK307b is $47.9 \pm 0.2 \mathrm{Ma}$ (Table 1$)$.

Total release of argon from biotite sample 04OK338 was achieved over 14 step-heating intervals $\left(570-1120^{\circ} \mathrm{C}\right)$, with ages ranging from ca. 49 to $44 \mathrm{Ma}$ for individual heating steps (Table DR4). The integrated age is 47.9 $\pm 0.7 \mathrm{Ma}$ (Table 1). Biotite from 04OK338 displays a plateau-like pattern for a large section of gas release. Size of step weighting of steps $2-14$ of the analysis yields a preferred plateaulike age of $48.0 \pm 0.1 \mathrm{Ma}$ over $97.1 \%$ of the total ${ }^{39} \mathrm{Ar}$ released (Fig. $11 \mathrm{C}$, Table 1). Like sample 04OK307b, inverse isochron analysis of sample 04OK338 gives an intercept age identical to that calculated for the plateau-like segment at $48.0 \pm 0.1 \mathrm{Ma}(1 \sigma, \mathrm{MSWD}=2.1$; Fig. $11 \mathrm{C})$. 
A $040 K 305$

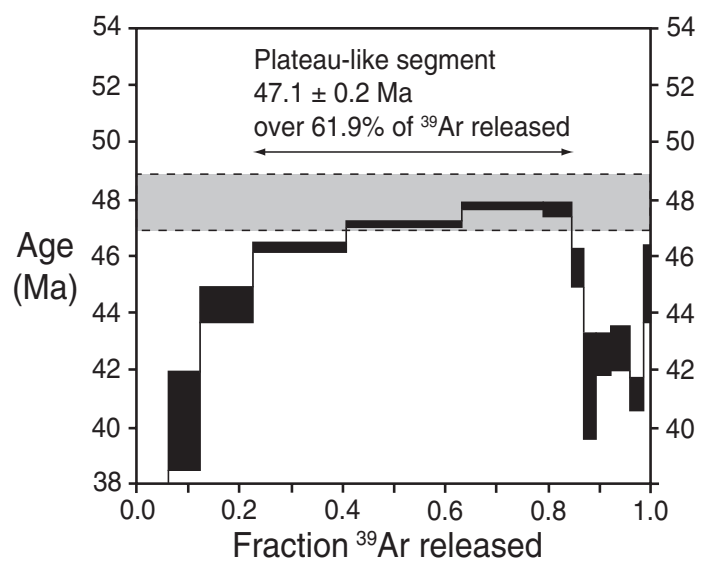

04OK307b

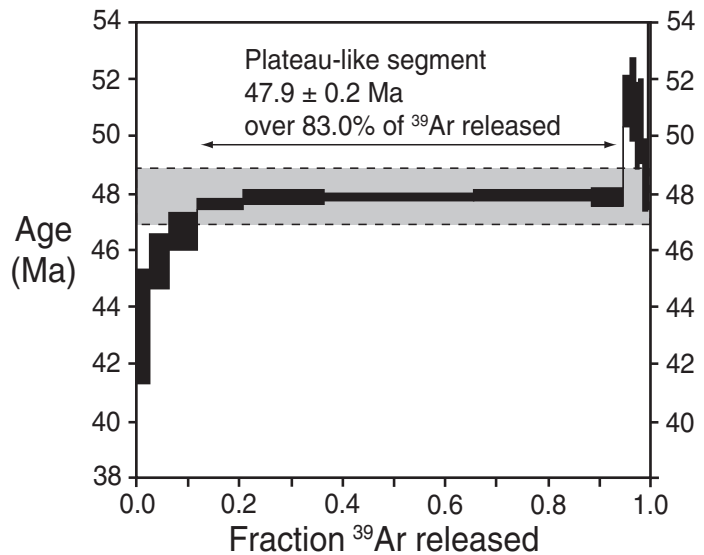

$040 K 338$

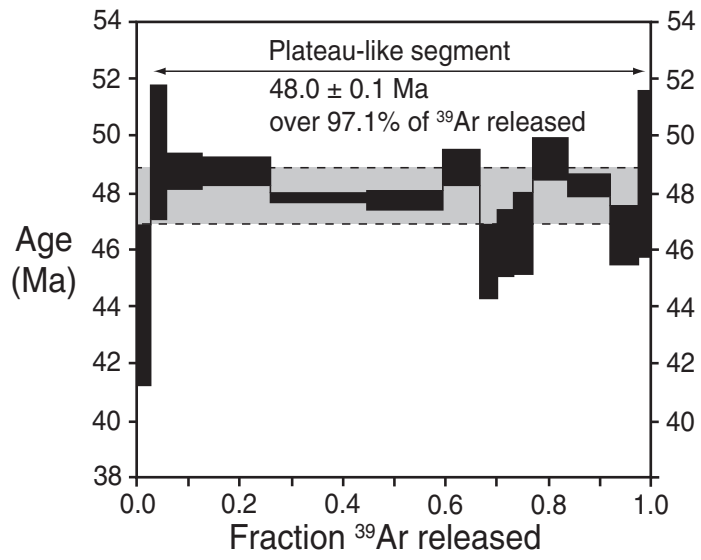

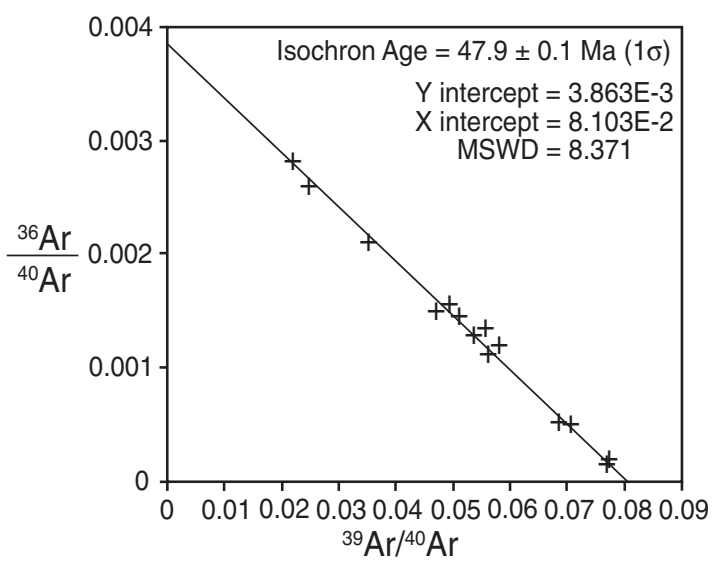
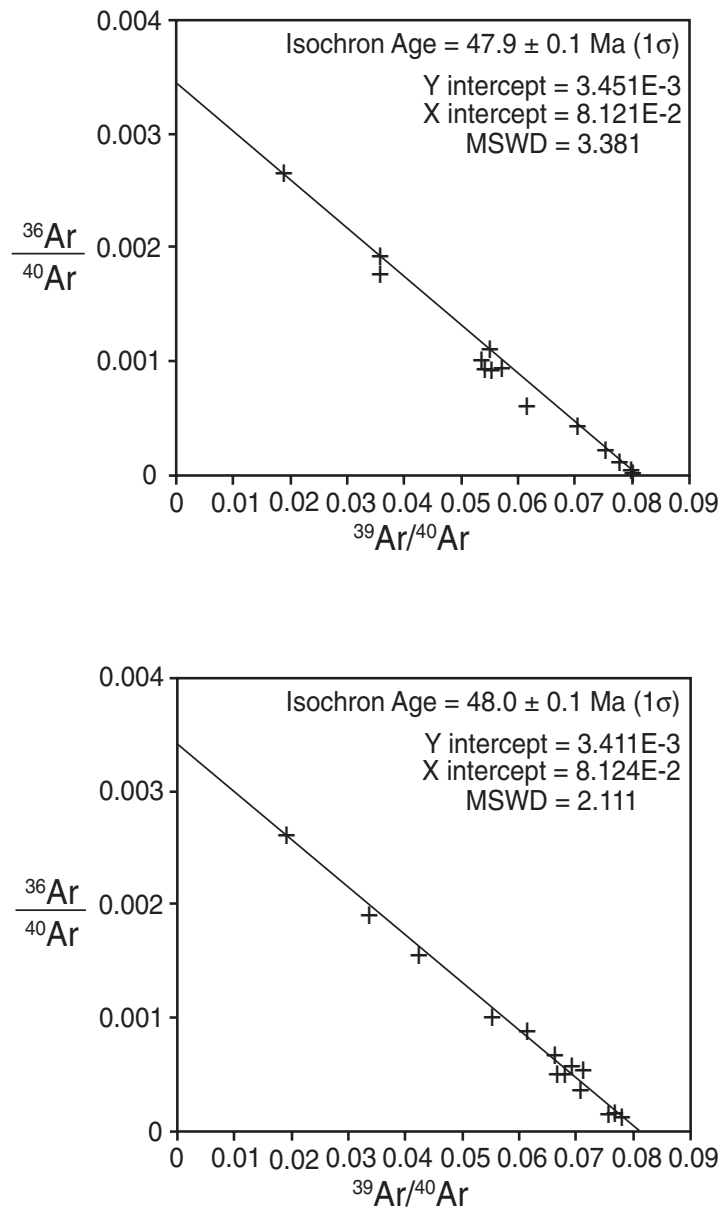

Figure 11. Age spectrum for stepwise release of argon and inverse isochron diagrams for the step-heating results of biotite samples (A) 04OK305, (B) 04OK307b, and (C) 04OK338. Note the similarity between the age of the selected plateau-like segments and the associated inverse isochron intercept age. Horizontal gray dashed interval is time window from 49 to $47 \mathrm{Ma}$, shown for clarifying temporal relationships among samples. 


\section{Samples with Partial Alteration of Biotite (040K304, 04OK311, and 04OK315)}

${ }^{40} \mathrm{Ar} /{ }^{39} \mathrm{Ar}$ results for biotite from samples 04OK304, 04OK311, and 04OK315 lack plateau-like features in the age spectra (Fig. 12). These biotite grains are partially altered to chlorite in discrete domains or along cleavages. In contrast, the three samples yielding plateau-like segments, described in the previous section, lack chlorite. ${ }^{40} \mathrm{Ar} /{ }^{39} \mathrm{Ar}$ ages for the altered biotite are scattered from ca. 46 to $17 \mathrm{Ma}$ (Table DR4), suggesting that the alteration has had a significant impact on the retention of radiogenic argon in the biotite host.

\section{INTERPRETATION OF THE GEOTHERMOCHRONOLOGY DATA}

U-Pb SHRIMP ages for zircon and monazite from Okanogan migmatite range from 85 to $49 \mathrm{Ma}$, although within this range only two samples (03OK80b and 03OK80c) contain phases dated at greater than $61 \mathrm{Ma}$. Zircon ${ }^{206} \mathrm{~Pb} /{ }^{238} \mathrm{U}$ ages in sample $03 \mathrm{OK} 80 \mathrm{~b}$, the wispy granodiorite diatexite in the core of the Stowe Mountain subdome, yield the largest range of ages with two populations at ca. 85 to $70 \mathrm{Ma}$ and ca. 57 to 49 Ma. Three possible interpretations could explain the Late Cretaceous ages. These ca. 85 to $70 \mathrm{Ma}$ ages may represent zircon crystallization related to regional metamorphism or an earlier migmatization episode. Both of these explanations are reasonable because the high-grade metamorphism of other domes in the Omineca belt has been dated as Jurassic to Cretaceous (Armstrong, 1982; Archibald et al., 1983). Alternatively, the range of ages may also reflect melting of heterogeneous source rocks (including plutons) and could therefore represent inherited ages.

The Paleocene to Eocene ages determined in sample $03 \mathrm{OK} 80 \mathrm{~b}$ from rims on older cores and from newly formed zircon in leucosome are recorded in all five samples (three diatexite and two metatexite). Based on structural evidence that indicates melt-present deformation, the structural context of the samples (Figs. 3 and 4A) and grain morphologies, these results are interpreted as the timing of migmatite crystallization. Within the diatexite, all samples have $\mathrm{U}-\mathrm{Pb}$ zircon ages for new zircon growth and rim overgrowths ranging from 61 to $49 \mathrm{Ma}$. All monazite grains analyzed are less than ca. 55 Ma. The oldest mean zircon age obtained (ca. 60 Ma; Figs. 4 and 7) is from a discordant leucosome in the metatexite domain (sample 04OK300a). Despite having the oldest calculated age of all the migmatite samples analyzed, a spread of ages to ca. $53 \mathrm{Ma}$ are

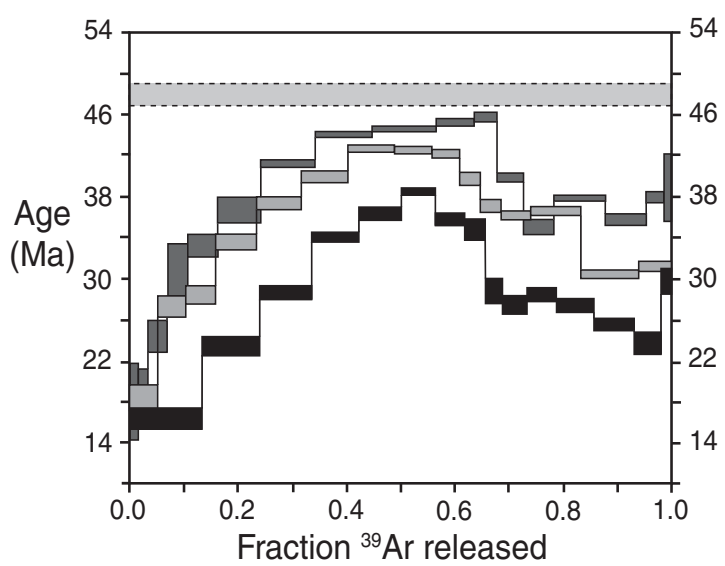

Figure 12. Combination plot of disturbed age spectrum for stepwise release of argon from samples 04OK304 (lower), $040 K 311$ (top), and 04OK315 (middle). Horizontal gray dashed interval is time window from 49 to 47 Ma shown for clarifying temporal relationships of samples with spectra reported in Figure 11.

clearly younger than the main age population at ca. $60 \mathrm{Ma}$. Field relationships clearly show this leucosome, along with discordant leucosome in the diatexite domain, to be the youngest in terms of crosscutting relations (Fig. 4A). Discordant leucosome in the structurally lower diatexite domain is dated at $53.5 \pm 0.5 \mathrm{Ma}$. This ca. $53 \mathrm{Ma}$ age is similar to the youngest ages obtained in sample 04OK300a, and is likely closer to the true geologic age of the discordant leucosome in the metatexite domain. We therefore interpret the bulk of ca. $60 \mathrm{Ma}$ ages in sample 04OK300a as inherited ages, likely derived from the host migmatites, during crystallization of the discordant leucosome.

Despite the complexities in resolving the age discrepancy in sample 04OK300a, all samples analyzed record Paleocene to Eocene ages for new zircon growth and rim overgrowths that we attribute to periods of migmatite crystallization. The Okanogan dome therefore records a complex deformational history and has a history of migmatite crystallization spanning $~ 12$ m.y. (ca. 61 to $49 \mathrm{Ma}$ range of ${ }^{206} \mathrm{~Pb} /{ }^{238} \mathrm{U}$ zircon and monazite ages) during Paleocene-Eocene time.

Following crystallization of the youngest leucosome, the rocks cooled rapidly from hightemperature through the closure temperature of Ar in biotite $\left(\sim 325^{\circ} \mathrm{C}\right)$. All rocks from the diatexite core to the detachment zone record ${ }^{40} \mathrm{Ar} /{ }^{39} \mathrm{Ar}$ biotite ages of ca. $48 \mathrm{Ma}$. U-Pb titanite ages are consistently ca. $47 \mathrm{Ma}$. These ages likely represent cooling (in zoned grains, core and rim ages are the same), and the similarity of biotite $\mathrm{Ar}$ ages and titanite $\mathrm{U}-\mathrm{Pb}$ ages indicate rapid cooling through $\sim 325{ }^{\circ} \mathrm{C}$ by ca. 48 to $47 \mathrm{Ma}$. Biotite and titanite ages overlap with ca. 54 to $48 \mathrm{Ma}$ ages of Okanogan-Kettle hornblende, biotite, and muscovite (Fox et al., 1976; Pearson and Obradovich, 1977; Holder and Holder, 1988; Berger and Snee, 1992).

Considering the time interval from the mean ${ }^{206} \mathrm{~Pb} /{ }^{238} \mathrm{U}$ age of $51.1 \pm 1.0 \mathrm{Ma}$ for the diatexite and the titanite ca. $47 \mathrm{Ma}$ age, these data indicate rapid cooling of $\sim 100^{\circ} \mathrm{C} / \mathrm{m}$.y. over the time interval 51 to $47 \mathrm{Ma}$ (i.e., from $>800$ to $325^{\circ} \mathrm{C}$ in 4 m.y.). Rapid cooling and the lack of difference in cooling age between the diatexite core and higher structural levels is likely related to rapid exhumation of the migmatite dome.

\section{CRYSTALLIZATION AND EXHUMATION OF MIGMATITES}

Our new data suggest that the Okanogan dome records at least 12 m.y. of migmatite crystallization during Paleocene to Eocene time. Based on our existing data it is not possible to distinguish whether partial melting and associated migmatite crystallization was achieved by a continuous process or the result of discontinuous events. For events prior to ca. $61 \mathrm{Ma}$, it is difficult to determine the duration of partial melting or whether the crust contained a significant volume of partial melt. In addition, the crust at current exposure levels represents a small fraction of the likely layer of former partially molten crust; therefore we have an incomplete view of the orogenic crust. However, we can consider at least two distinct cases for the duration of partial melting, and discuss the likely consequences of each model.

Crustal melting may have been a protracted event, starting during Late Cretaceous crustal 


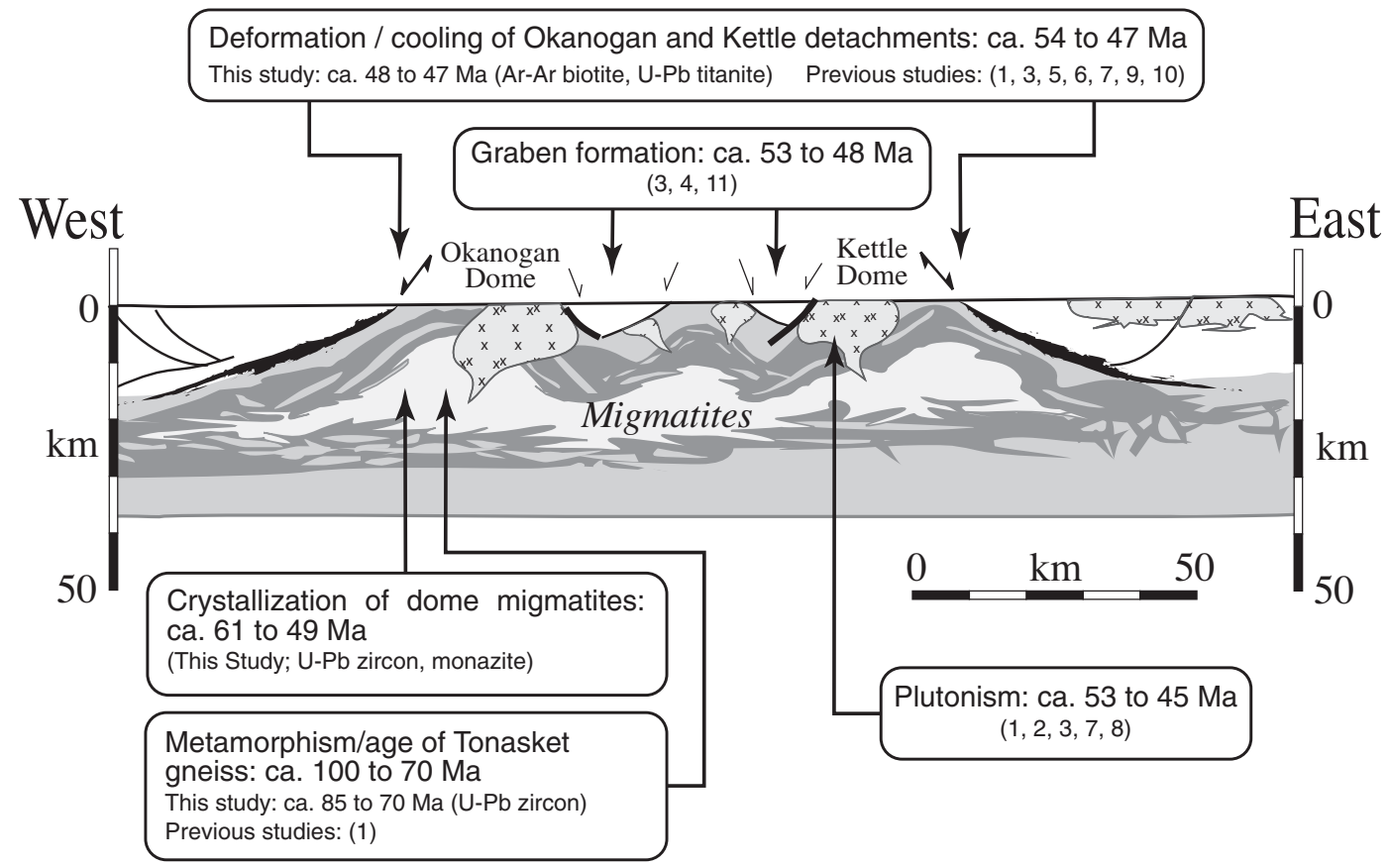

Figure 13. Schematic cross section and summary of timing relationships in the OkanoganKettle metamorphic core complex. References are: 1-Fox et al. (1976); 2-Fox et al. (1977); 3-Pearson and Obradovich (1977); 4-Atwater (1985); 5-Parkinson (1985); 6-Tempelman-Kluit and Parkinson (1986); 7-Holder and Holder (1988); 8-Carlson and Moye (1990); 9-Berger and Snee (1992); 10—Box and Wooden (1994); 11-Suydam and Gaylord (1997). thickening and metamorphism, and continuing until cooling and exhumation in the early Tertiary. According to this model, the U-Pb results of this study are minimum ages for the time interval in which the Omineca Belt contained significant amounts of partially molten crust, and, if so, the duration of migmatization may have spanned $\sim 35$ m.y. Alternatively, Cretaceous crustal thickening may not have resulted in generation of abundant migmatite, and partial melting occurred primarily in the early Tertiary. In this scenario, the duration of partial melting events is shorter-perhaps not much longer than the time indicated by the crystallization ages of zircon and monazite ( 12 m.y.). An implication of this model is that partial melting and extension were linked; i.e., the presence of high-melt fraction crust may have facilitated extension (e.g., Vanderhaeghe and Teyssier, 2001), and the feedback between decompression and further partial melting may have enhanced the production and exhumation of partially molten crust (Teyssier and Whitney, 2002). Elucidating the relationships among these processes is difficult in the case of the northern Cordillera because regional extension could have been driven by (1) slowed convergence and the onset of major dextral transcurrent motion along the western boundary of North America (Price, 1979; Price and Carmichael, 1986) or extension triggered by rollback of the subducted slab (Parrish et al., 1988); or (2) thermal weakening following Laramide orogenesis and extensive Early Cenozoic magmatism (Armstrong, 1982; Coney and Harms, 1984).
Whether partial melting was a continuous or episodic event spanning 12 m.y. or longer, it is clear that melt crystallization is kinematically linked to the structural development of the Okanogan dome, that the Okanogan dome has been thoroughly reworked by high-grade metamorphism and crustal melting, and is not simply exhumed "old basement." Dynamic and temporal relationships among doming, detachment faulting, and brittle faulting (basin formation) are observed throughout the southern Omineca Belt, suggesting that the Cordillera hinterland underwent orogenic collapse in the presence of melt. Tertiary partial melting has been documented over a widespread area within the Shuswap complex (400 km north-south), including the Frenchman Cap dome (Crowley et al., 2001), Thor-Odin dome (Vanderhaeghe et al., 1999, 2003; Hinchey et al., 2006), Valhalla (Spear and Parrish, 1996; Spear, 2004; Gordon et al., 2008), and Okanogan dome (this study).

The tectonothermal evolution of the domes and core complexes to the north of the Okanogan complex has been interpreted to suggest that extension and exhumation were in part concentrated at the boundary between the cold foreland (Rocky Mountains) and the more melt-rich hinterland (Omineca Belt) (Teyssier et al., 2005). Results from the Okanogan region document that migmatite crystallization and exhumation, detachment tectonics, and basin formation (Fig. 13) were temporally and kinematically linked, in a region as far as $200 \mathrm{~km}$ west of the hinterland-foreland boundary in
Paleocene to Eocene time (Fig. 1). These data further suggest that melt-rich orogens, once subjected to kinematic or thermal changes, rapidly exhume deep orogenic crust and cool rapidly_essentially ending orogeny.

\section{ACKNOWLEDGMENTS}

This research is supported by National Science Foundation grant EAR-0409776 to Teyssier and Whitney, a Geological Society of America research grant to Kruckenberg, and the Department of Geology and Geophysics Graduate Research Fund at the University of Minnesota. Insightful reviews and editorial comments by James Crowley, William McClelland, Elizabeth Miller, and Cees van Staal greatly improved this manuscript. We thank the Australian Nuclear Science Technology Organization and the Australian Institute of Nuclear Science and Engineering for facilitating neutron irradiations of biotite. We also thank Dr. Annia Fayon, Christine Regalla, Rebecca-Ellen Farrell, the support and analytical staff at Australian National University and the University of Minnesota, and the Washington state landowners who provided access to conduct this research.

\section{REFERENCES CITED}

Archibald, D.A., Glover, J.K., Price, R.A., Farrar, E., and Carmichael, D.M., 1983, Geochronology and tectonic implications of magmatism and metamorphism, southern Kootenay arc and neighbouring regions, southeastern British Columbia. Part I: Jurassic to midCretaceous: Canadian Journal of Earth Sciences, v. 20, p. 1891-1913.

Armstrong, R L. 1982, Cordilleran metamorphic core complexes-From Arizona to southern Canada: Annua Review of Earth and Planetary Sciences, v. 10, p. 129-154, doi: 10.1146/annurev.ea.10.050182.001021.

Atwater, B.R., 1985, Contemporaneity of the Republic Graben and Okanogan gneiss dome-Evidence from the Coyote Creek pluton, southern Okanogan County, 
Washington: Geological Society of America Abstracts with Programs, v. 17, p. 338

Babeyko, A.Y., Sobolev, S.V., Trumbull, R.B., Oncken, O., and Lavier, L.L., 2002, Numerical models of crustal scale convection and partial melting beneath the Altiplano-Puna Plateau: Earth and Planetary Science Letters, v. 199, p. 373-388, doi: 10.1016/S0012821X(02)00597-6.

Beaumont, C., Jamieson, R.A., Nguyen, M.H., and Lee, B. 2001, Himalayan tectonics explained by extrusion of a low-viscosity crustal channel coupled to focused surface denudation: Nature, v. 414 , p. $738-742$, doi: 10.1038/414738a.

Berger, B.R., and Snee, L.W., 1992, Thermochronologic constraints on mylonite and detachment fault development, Kettle Highlands, northeastern Washington and southern British Columbia: Geological Society of America Abstracts with Programs, v. 24, p. 65

Bertotti, G., Podladchikov, Y., and Daehler, A., 2000, Dynamic link between the level of ductile crustal flow and style of normal faulting of brittle crust: Tectonophysics, v. 320 p. 195-218, doi: 10.1016/S0040-1951(00)00045-7.

Box, S.E., and Wooden, J.L., 1994, New age data on Kettle and Okanogan dome detachments, northeastern Washington: Geological Society of America Abstracts with Programs, v. 26, p. 40.

Brown, M., 1994, The generation, segregation, ascent and emplacement of granite magma: The migmatite-tocrustally-derived granite connection in thickened orogens: Earth-Science Reviews, v. 36, p. 83-130, doi: 10.1016/0012-8252(94)90009-4.

Brown, M., and Solar, G.S., 1998, Shear-zone systems and melts: Feedback relations and self-organization in orogenic belts: Journal of Structural Geology, v. 20, p. 211-227, doi: 10.1016/S0191-8141(97)00068-0.

Brown, R.L., and Read, P.B., 1983, Shuswap Terrane of British Columbia: A Mesozoic "core complex": Geology, v. 11 , p. $164-168$, doi: 10.1130/0091-7613(1983)11<1 64: $\mathrm{STOBCA}>2.0 . \mathrm{CO} ; 2$

Carlson, D.H., and Moye, F.J., 1990, The Colville igneous complex: Paleogene volcanism, plutonism, and extension in northeastern Washington, in Anderson, J.L., ed., The nature and origin of Cordilleran magmatism: Geological Society of America Memoir, v. 174, p. 375-394.

Cheney, E.S., 1980, Kettle dome and related structures of northeastern Washington, in Crittenden, M.D., Coney, P.J., and Davis, G.H., eds., Cordilleran metamorphic complexes: Geological Society of America Memoir, v. 153 , p. $463-483$.

Clark, M.K., and Royden, L.H., 2000, Topographic ooze: Building the eastern margin of Tibet by lower crustal flow: Geology, v. 28, p. 703-706, doi: 10.1130/0091-7 613(2000)28<703:TOBTEM>2.0.CO;2.

Coney, P.J., 1980, Cordilleran metamorphic core complexes: An overview, in Crittenden, M.D., Coney, P.J., and Davis, G.H., eds., Cordilleran metamorphic core complexes: Geological Society of America Memoir, v. 153, p. 7-31.

Coney, P.J., and Harms, T.A., 1984, Cordilleran metamorphic core complexes: Cenozoic extensional relics of Mesozoic compression: Geology, v. 12, p. 550-554, doi: 10.1 130/0091-7613(1984)12<550:CMCCCE >2.0.CO; 2.

Crittenden, M.D., Coney, P.J., and Davis, G.H., 1980, Cordilleran metamorphic core complexes: Geological Society of America Memoir, v. 153, 490 p.

Crowley, J.L., Brown, R.L., and Parrish, R.R., 2001, Diachronous deformation and a strain gradient beneath the Selkirk allochthon, northern Monashee complex, southeastern Canadian Cordillera: Journal of Structura Geology, v. 23, p. 1103-1121, doi: 10.1016/S0191-8141 (00)00179-6

Doughty, P.T., and Price, R.A., 1999, Tectonic evolution of the Priest River complex, northern Idaho and Washington: A reappraisal of the Newport fault with new insights on metamorphic core complex formation: Tectonics, v. 18 , p. 375-393, doi: 10.1029/1998TC900029.

Fox, K.F., Jr., Rinehart, C.D., Engels, J.C., and Stern, T.W., 1976, Age of emplacement of the Okanogan gneiss dome, north-central Washington: Geological Society of America Bulletin, v. 87,p. 1217-1224, doi: 10.1130/001 6-7606(1976)87<1217:AOEOTO>2.0.CO;2.

Fox, K.F., Jr., Rinehart, C.D., and Engels, J.C., 1977, Plutonism and orogeny in north-central Washington: Tim- ing and regional context: U.S. Geological Survey Professional Paper, $27 \mathrm{p}$.

Gans, P.B., 1987, An open system, two-layer crustal stretching model for the eastern Great Basin: Tectonics, v. 6, p. $1-12$.

Goodge, J.W., and Hansen, V.L., 1983, Petrology and structure of rocks in the southwest portion of Okanogan dome, north-central Washington: Northwest Geology, v. 12, p. $13-24$.

Gordon, S.M., Whitney, D.L., Teyssier, C., Grove, M., and Dunlap, W.J., 2008, Timescales of migmatization, melt crystallization, and cooling in a Cordilleran gneiss dome, the Valhalla Complex, southeastern British Columbia: Tectonics, in press.

Hansen, V.L., and Goodge, J.W., 1988, Metamorphism, structural petrology, and regional evolution of the Okanogan Complex, northeastern Washington: Rubey colloquium on metamorphism and crustal evolution of the Western United States, v. 7, p. 233-270.

Harvey, J.L., 1994, Sapphirine-bearing amphibolites in the Okanogan complex, Washington: Thermobarometry and tectonic implications [M.S. thesis]: Northern Arizona University, $237 \mathrm{p}$.

Hinchey, A.M., Carr, S.D., McNeill, P.D., and Rayner, N. 2006, Paleocene-Eocene high-grade metamorphism, anatexis and deformation in the Thor-Odin dome, Monashee complex, southeastern British Columbia: Canadian Journal of Earth Sciences, v. 43, p. 1341-1365, doi: 10.1139/E06-028

Holder, R.W., and Holder, G.A., 1988, The Colville Batholith: Tertiary plutonism in northeast Washington associated with graben and core-complex (gneiss dome) formation: Geological Society of America Bulletin, v. 100 p. 1971-1980, doi: 10.1130/0016-7606(1988)100<1971: TCBTPI>2.3.CO;2.

Jamieson, R.A., Beaumont, C., Nguyen, M.H., and Lee, B., 2002, Interaction of metamorphism, deformation and exhumation in large convergent orogens: Journal of Metamorphic Geology, v. 20, p. 9-24, doi: 10.1046/j.02634929.2001.00357.x

Keay, S., Lister, G., and Buick, I., 2001, The timing of partial melting, Barrovian metamorphism and granite intrusion in the Naxos metamorphic core complex, Cyclades, Aegean Sea, Greece: Tectonophysics, v. 342, p. 275-312, doi: 10.1016/S0040-1951(01)00168-8.

Ledru, P., Courrioux, G., Dallain, C., Lardeaux, J.M., Montel, J.M., Vanderhaeghe, O., and Vitel, G., 2001, The Velay Dome (French Massif Central): Melt generation and granite emplacement during orogenic evolution: Tectonophysics, v. 342, p. 207-237, doi: 10.1016/ S0040-1951(01)00165-2.

Lister, G.S., and Davis, G.A., 1989, The origin of metamorphic core complexes and detachment faults formed during Tertiary continental extension in the northern Colorado River region, U.S: Journal of Structural Geology, v. 11, p. 65-94, doi: 10.1016/0191-8141(89)90036-9.

Ludwig, K.R., 2003, User's manual for Isoplot/Ex, Version 3.0, A geochronological toolkit for Microsoft Excel: Berkeley Geochronology Center Special Publication No. 4.

MacCready, T., Snoke, A.W., Wright, J.E., and Howard, K.A., 1997, Mid-crustal flow during Tertiary extension in the Ruby Mountains core complex, Nevada: Geological Society of America Bulletin, v. 109, p. 1576-1594 doi: 10.1130/0016-7606(1997)109<1576:MCFDTE> 2.3. $\mathrm{CO} ; 2$.

Marchildon, N., and Brown, M., 2002, Grain-scale melt distribution in two contact aureole rocks: Implications for controls on melt localization and deformation: Journal of Metamorphic Geology, v. 20, p. 381-396, doi 10.1046/j.1525-1314.2002.00376.x

Marchildon, N., and Brown, M., 2003, Spatial distribution of melt-bearing structures in anatectic rocks from Southern Brittany, France: Implications for melt transfer at grainto orogen-scale: Tectonophysics, v. 364, p. 215-235, doi: 10.1016/S0040-1951(03)00061-1.

McKenzie, D., Nimmo, F., Jackson, J.A., Gans, P.B., and Miller, E.L., 2000, Characteristics and consequences of flow in the lower crust: Journal of Geophysical Research, B, Solid Earth and Planets, v. 105, p. 11,029-11,046, doi: 10.1029/1999JB900446.

McLellan, E.L., 1988, Migmatite structures in the Central Gneiss Complex, Boca de Quadra, Alaska: Journa of Metamorphic Geology, v. 6 (4), p. 517-542, doi: 10.1111/j.1525-1314.1988.tb00437.x.

Menzer, F.J., Jr., 1983, Metamorphism and plutonism in the central part of the Okanogan Range, Washington: Geological Society of America Bulletin, v. 94, p. 471-498, doi: 10.1130/0016-7606(1983)94<471:MAPITC >2.0 .CO;2.

Monger, J.W.H., Price, R.A., and Tempelman-Kluit, D.J., 1982, Tectonic accretion and the origin of the two major metamorphic and plutonic welts in the Canadian Cordillera: Geology, v. 10, p. 70-75, doi: 10.1130/0091-7613( 1982) $10<70$ :TAATOO $>2.0$. CO;2

Nelson, K.D., Wenjin, Z., Brown, L.D., Kuo, J., Jinkai, C. Xianwen, L., Klemperer, S.L., Makovsky, Y., Meissner, R., Mechie, J., Kind, R., Wenzel, F., Ni, J., Nabelek, J., Leshou, C., Handong, T., Wenbo, W., Jones, A.G. Booker, J., Unsworth, M., Kidd, W.S.F., Hauck, M., Alsdorf, D., Ross, A., Cogan, M., Wu, C., Sandvol, E.A and Edwards, M., 1996, Partially molten middle crust beneath southern Tibet: Synthesis of Project INDEPTH results: Science, v. 274, p. 1684-1688, doi: $10.1126 /$ science. 274.5293.1684

Okulitch, A.V., 1984, The role of the Shuswap metamorphic complex in Cordilleran tectonism: A review: Canadian Journal of Earth Sciences, v. 21, p. 1171-1193.

Parkinson, D., 1985, Geochronology of the western side of the Okanogan metamorphic core complex, southern B.C: Geological Society of America Abstracts with Programs, v. 17, p. 399

Parrish, R.R., Carr, S.D., and Parkinson, D.L., 1988, Eocene extensional tectonics and geochronology of the southern Omineca Belt, British Columbia and Washington: Tectonics, v. 7, p. 181-212.

Pearson, R.C., and Obradovich, J.D., 1977, Eocene rocks in northeast Washington: Radiometric ages and correlation: U. S. Geological Survey Bulletin, 41 p.

Pous, J., Munoz, J.A., Ledo, J.J., and Liesa, M., 1995, Partial melting of subducted continental lower crust in the Pyrenees: Journal of the Geological Society, v. 152, p. 217-220, doi: 10.1144/gsjgs.152.2.0217.

Price, R.A., 1979, Intracontinental ductile crustal spreading linking the Fraser River and Northern Rocky Mountain Trench transform fault zones, south-central British Columbia and northeast Washington: Geological Society of America Abstracts with Programs, v. 11, p. 499.

Price, R.A., and Carmichael, D.M., 1986, Geometric test for Late Cretaceous-Paleogene intracontinental transform faulting in the Canadian Cordillera: Geology, v. 14 p. 468-471, doi: 10.1130/0091-7613(1986)14<468:GT FLCI $>2.0 . \mathrm{CO} ; 2$

Rey, P., Vanderhaeghe, O., Teyssier, C., Teyssier, C., and Vanderhaeghe, O., 2001, Gravitational collapse of the continental crust: Definition, regimes and modes: Tectonophysics, v. 342, p. 435-449, doi: 10.1016/S00401951(01)00174-3.

Royden, L., 1996, Coupling and decoupling of crust and mantle in convergent orogens: Implications for strain partitioning in the crust: Journal of Geophysical Research, B Solid Earth and Planets, v. 101, p. 17,679-17,705, doi 10.1029/96JB00951.

Royden, L.H., Burchfiel, B.C., King, R.W., Wang, E., Zhiliang, C., Feng, S., and Yuping, L., 1997, Surface deformation and lower crustal flow in eastern Tibet: Science, v. 276, p. 788-790, doi: 10.1126/science. 276.5313.788.

Schilling, F.R., and Partzsch, G.M., 2001, Quantifying partial melt fraction in the crust beneath the Central Andes and the Tibetan Plateau: Physics and Chemistry of the Earth, v. 26, p. 239-246, doi: 10.1016/S14641895(01)00051-5.

Snook, J.R., 1965, Metamorphic and structural history of "Colville batholith" gneisses, north-central Washington: Geological Society of America Bulletin, v. 76, p. 759-776, doi: 10.1130/0016-7606(1965)76[759:MA SHOC]2.0.CO;2.

Soula, J., Debat, P., Brusset, S., Bessiere, G., Christophoul, F., and Deramond, J., 2001, Thrust-related, diapiric, and extensional doming in a frontal orogenic wedge: Example of the Montagne Noire, Southern French Hercynian Belt: Journal of Structural Geology, v. 23, p. 1677-1699, doi: 10.1016/S0191-8141(01)00021-9.

Spear, F.S., 2004, Fast cooling and exhumation of the Valhalla metamorphic core complex, southeastern British Colum- 
bia: International Geology Review, v. 46, p. 193-209, doi: 10.2747/0020-6814.46.3.193.

Spear, F.S., and Parrish, R.R., 1996, Petrology and cooling rates of the Valhalla Complex, British Columbia, Canada: Journal of Petrology, v. 37, p. 733-765, doi 10.1093/petrology/37.4.733.

Stoffel, K.L., Joseph, N.L., Waggoner, S.Z., Gulick, C.W., Korosec, M.A., and Bunning, B.B., 1991, Geologic map of Washington, northeast quadrant: Washington Division of Geology and Earth Resources Geologic Map, v. GM-39, p. 36.

Suydam, J.D., and Gaylord, D.R., 1997, Toroda Creek half graben, northeast Washington: Late-stage sedimentary infilling of a synextensional basin: Geological Societ of America Bulletin, v. 109, p. 1333-1348, doi: 10.1130/ 0016-7606(1997)109<1333:TCHGNW>2.3.CO;2.

Tempelman-Kluit, D.J., and Parkinson, D., 1986, Extension across the Eocene Okanagan crustal shear in southern British Columbia: Geology, v. 14, p. 318-321, doi: 10.1 130/0091-7613(1986)14<318:EATEOC>2.0.CO;2.
Teyssier, C., and Whitney, D.L., 2002, Gneiss domes and orogeny: Geology, v. 30, p. 1139-1142, doi: 10.1130/00 91-7613(2002)030<1139:GDAO>2.0.CO;2.

Teyssier, C., Ferré, E.C., Whitney, D.L., Norlander, B., Vanderhaeghe, O., and Parkinson, D., 2005, Flow of partially molten crust and origin of detachments during collapse of the Cordilleran Orogen, in Bruhn, D., and Burlini, L., High-strain zones: Structure and physical properties: Geological Society [London] Special Publications, v. 245 , p. $39-64$.

Vanderhaeghe, O., and Teyssier, C., 2001, Partial melting and flow of orogens: Tectonophysics, v. 342, p. 451-472, doi: 10.1016/S0040-1951(01)00175-5.

Vanderhaeghe, O., Teyssier, C., and Wysoczanski, R., 1999, Structural and geochronological constraints on the role of partial melting during the formation of the Shuswap metamorphic core complex at the latitude of the Thor-Odin Dome, British Columbia: Canadian Journal of Earth Sciences, v. 36, p. 917-943, doi: 10.1139/ cjes-36-6-917.
Vanderhaeghe, O., Teyssier, C., McDougall, I., and Dunlap, W.J., 2003, Cooling and exhumation of the Shuswap metamorphic core complex constrained by ${ }^{40} \mathrm{Ar}-{ }^{39} \mathrm{Ar}$ thermochronology: Geological Society of America Bulletin, v. 115, p. 200-216, doi: 10.1130/0016-7606(2003) 115<0200:CAEOTS >2.0.CO;2.

Whitney, D.L., Teyssier, C., Fayon, A.K., Hamilton, M.A., and Heizler, M., 2003, Tectonic controls on metamorphism, partial melting, and intrusion: Timing of regional metamorphism and magmatism of the Ni de Massif, Turkey: Tectonophysics, v. 376, p. 37-60, doi: 10.1016/j. tecto.2003.08.009.

Whitney, D.L., Teyssier, C., and Siddoway, C.S., eds., 2004, Gneiss domes in orogeny: Geological Society of America Special Paper, v. 380, 393 p.

Manuscript Received 13 November 2006 ReVised Manuscript Received 19 November 2007 ManusCript ACCEPTEd 7 December 2007

Printed in the USA 